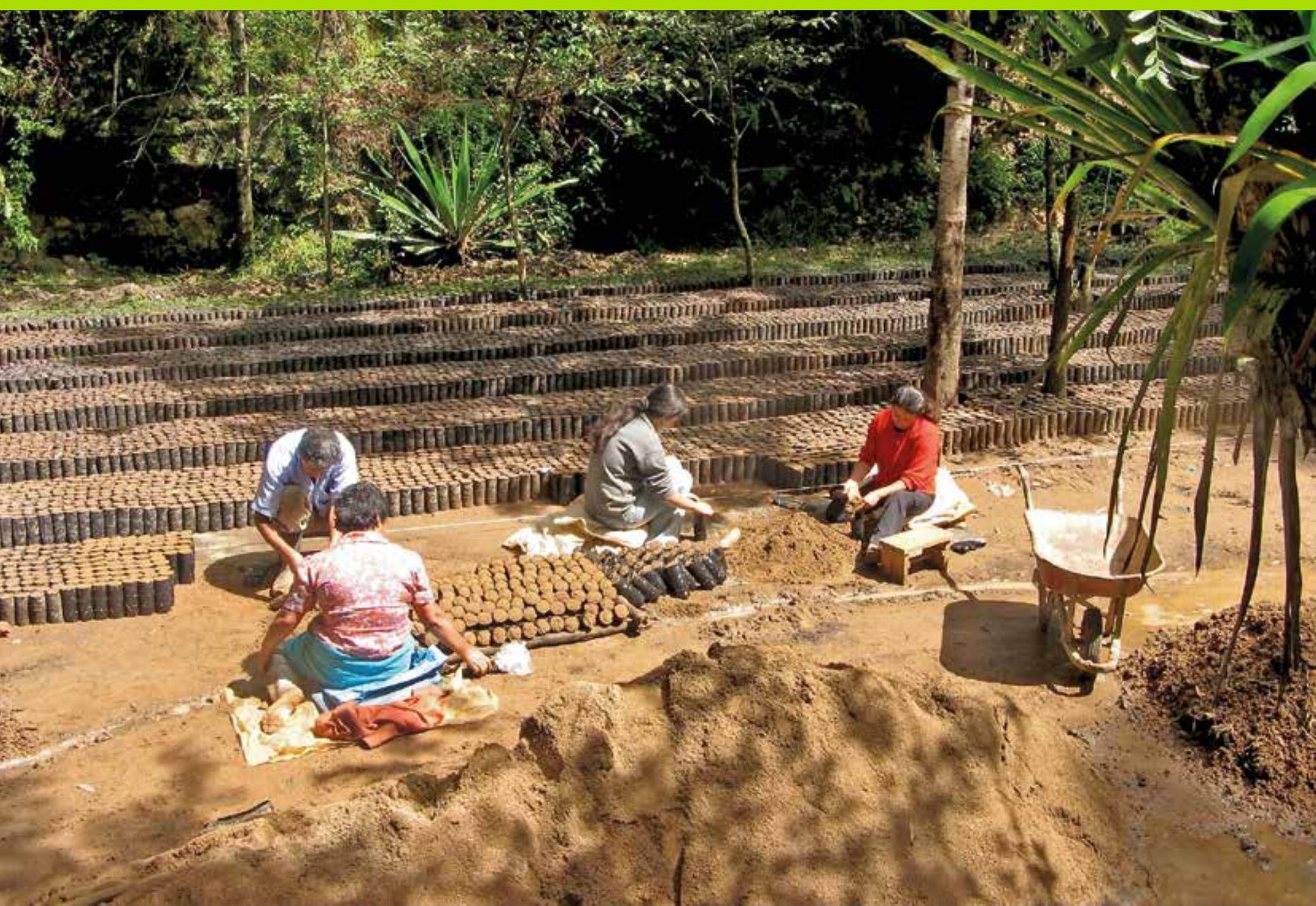

\title{
Gender in the CGIAR Research Program on Forests, Trees and Agroforestry
} A strategy for research and action

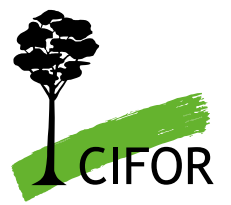

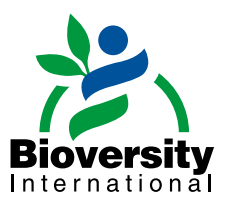

ÆCIAT

cirad 



\section{Gender in the CGIAR Research Program on Forests, Trees and Agroforestry}

A strategy for research and action 
(c) 2013 Center for International Forestry Research All rights reserved

CIFOR. 2013. Gender in the CGIAR Research Program on Forests, Trees and Agroforestry: A strategy for research and action. CIFOR, Bogor, Indonesia.

Photo cover by Anne Larson/CIFOR

Altiplano, Guatemala.

CIFOR

Jl. CIFOR, Situ Gede

Bogor Barat 16115

Indonesia

$\mathrm{T}+62(251) 8622-622$

$\mathrm{F}+62(251) 8622-100$

E cifor@cgiar.org

cifor.org 


\section{Table of contents}

$\begin{array}{ll}\text { Introduction } & 1\end{array}$

$\begin{array}{lr}\text { Rationale } & 2\end{array}$

$\begin{array}{ll}\text { Goals and objectives } & 4\end{array}$

$\begin{array}{lr}\text { Impact pathways } & 8\end{array}$

$\begin{array}{ll}\text { Activities } & 10\end{array}$

A. Collection of sex-disaggregated data and gender analysis $\quad 10$

B. Partnerships and alliances to enhance gender inclusiveness $\quad 11$

C. Knowledge sharing for gender-responsive policy and practice 12

D. Adaptive learning for gender-responsive research and analysis 13

$\begin{array}{ll}\text { Capacity for gender research and analysis } & 14\end{array}$

Monitoring and evaluation $\quad 16$

Implementing the monitoring and evaluation plan 17

\begin{tabular}{l|l} 
References & 21
\end{tabular}

Annex I: Gender-specific research questions across the five components 23 


\section{List of figures, tables and boxes}

\section{Figures}

1 Gender box: A framework for the analysis and synthesis of gender in forest, tree and agroforestry systems

2 Gender impact pathway

3 Approaches for achieving gender inclusion (red boxes) at each phase of the research cycle (blue boxes)

\section{Tables}

1 Consideration of gender differentials and equality across the research components

2 Capacity for gender research and analysis in the CRP6

3 Summary of monitoring and evaluation plan

4 CRP6 gender budget

\section{Box}

1 CRP6 research components 


\section{Introduction}

Social attributes such as gender, wealth, age, ethnicity, migration status and religion can confer systematic disadvantages by making it difficult for some groups and individuals to access public and private mechanisms of resource allocation or decision making. In this strategy, we set out possibilities for strengthening how we address gender concerns in the CGIAR Research Program on Forests, Trees and Agroforestry (CRP6). The strategy focuses on the management support processes and structures needed to improve the quality and volume of gender-responsive research in the CRP6, and is closely aligned with the CGIAR Consortium's gender strategy. It synthesises gender-relevant research questions, outcomes and associated impact pathways that have been identified across CRP6's five research components. It recognises, however, that gender-based disadvantages may not always be the most urgent in all settings and that substantial differentiation can exist among men and women and not only between them. Thus, while this strategy is clearly marked out as a gender strategy, our agenda is broader. We envision that a careful use of participatory methodologies, including in problem framing, provides good scope for locating the most salient features of disadvantage in each research setting and for ensuring their inclusion in the research and action process. Overall, this strategy views gender integration in research as a fundamental part of doing good science and approaches gender integration as a cross-cutting theme, which integrates gender analysis and research into each of the five components/research programmes of the CRP6. 


\section{Rationale}

Despite a wealth of studies demonstrating the critically important roles women play in managing forests, agroforestry and tree genetic resources, women's contributions remain underappreciated. Women are traditionally the main collectors of fuelwood, medicinal and aromatic plants and other non-timber forest products (NTFPs) from forest and agroforestry landscapes (Shanley and Gaia 2001, Colfer 2005). Their participation in decision making at household and community levels, although limited, has been demonstrated to improve forest regeneration (Agarwal 2007, 2009), increase crop yields, improve financial management (Acharya and Gentle 2006) and prioritise funding for pro-poor and empowerment programmes (Komarudin et al. 2008). Women in forest communities can generate more than $50 \%$ of their income from forests, compared with about one-third for men (World Bank et al. 2009). Non-timber forest products (NTFPS) are particularly important for women. In Cameroon, for example, close to $90 \%$ of NTFP traders in up to 25 markets were women, while in other cases women have been found to earn up to $30 \%$ of their incomes from NTFPs (Ruiz Perez et al. 2002, Lemenih 2003). In Asia, the sale of NTFPs such as wild fruits and vegetables often provides the only source of cash available to landless women (Carr and Hartl 2008). Similar results are evident in agroforestry, where women derive substantial cash benefits from indigenous fruits and vegetables (Kiptot and Franzel 2012). Women's control over income correlates positively with improved food intake and child nutrition status (Kennedy and Peters 1992, Engle 1993, Hoddinott and Haddad 1995, Smith et al. 2003). Recent global surveys of the Poverty and Environment Network show that women are the primary collectors of wild foods, especially in Africa and Asia (Sunderland et al. under review). Wild foods supply micronutrients, which are often deficient in local diets (Howard and Nabanoga 2007). They also fill gaps during times of food shortage.

\section{Although the policy environment for addressing} gender inequity has improved over the past decade, women continue to be disadvantaged by insecure access and property rights to forest, trees and land resources (Quisumbing et al. 2001, Meinzen-
Dick et al. 2010), by discrimination and male bias in the provision of services including credit and technology (Place 1995) and by exclusion from decision making at household, community and national levels. Global comparative analyses confirm the general low levels of women's participation, which have been demonstrated by numerous case studies across different settings over the past two decades. Women participate much less than men in forest user groups, where decision rules regarding forest use, management and benefit distribution are made (Sunderland $e t$ al. under review, Coleman and Mwangi 2013). In addition, forest user groups with high proportions of women, as against gender-balanced groups, or groups with higher proportions of men, perform less well on key governance indicators (Mwangi et al. 2001, Sun et al. 2011). Carefully crafted longitudinal studies show that there is a threshold percentage below which women's effectiveness in leadership of forest user group committees declines, and that there are significant gains to forest sustainability with women's participation in forest governance (Agarwal 2007, 2009). In agroforestry and tree management, the results are mixed (Kiptot and Franzel 2012). Overall, however, women disproportionately bear the costs of tree and forest management, realise only a fraction of the benefits and tend to be enlisted for decision making only when forest and tree resources are degraded (Agrawal and Chhatre 2006). Moreover, women's lack of formal education, employment and personal networks makes them poorly placed to influence resource allocation or research (Crewe and Harrison 1998, Ferrier 2002).

Changes in tree cover and loss of community access to forests and trees can thus have a disproportionately adverse impact on women, with indirect impacts on households, and, consequently, on the livelihoods of up to 5-10 times as many people. Gender equity in the forestry and agroforestry sector can contribute to the achievement of broader social and economic goals, including the Millennium Development Goals.

Clearly, research suggests that effective gender inclusion can not only enhance the prospects for sustainable forest and tree management, but can 
also provide a solid foundation for more equitable benefit distribution, and household food security and nutrition. It enhances the credibility of policy and practice and allows for better targeting of interventions. However, significant knowledge gaps also exist (Mai et al. 2011, Kiptot and Franzel 2012). These include:

1. understanding the effectiveness of the recent wave of tenure reforms aimed at strengthening women's rights to forest and tree resources;

2. identifying gender-differentiated implications of global processes such as climate mitigation and adaptation, and large-scale land acquisitions, on resource access, livelihoods, opportunities and on gender relations;

3. designing and implementing strategies for the gender-equitable distribution of forest and tree benefits, including distribution of incomes between men and women;

4. designing organisational incentives and strategies for enhancing gender-responsive policy implementation;

5. identifying cultural taboos influencing the use and management of forests and trees, including tree planting and the adoption of innovative technologies; and

6. increasing women's participation influence along the value chains of forest and tree products, and their control of incomes and related benefits.

As elaborated in the following sections and in Annex I, gender research in the CRP6 will seek to address many of these knowledge gaps. In particular, the integration of gender in research is aimed at achieving one overriding outcome across the global settings and contexts where CRP6 and its partners are operational. This outcome is:

Women are better empowered, and gender equality in decision making and control over forest, tree and agroforestry resources use, management and benefits is improved.

The achievement of this outcome will be tracked using the following measurable indicators, which will be further refined and tested in the lifespan of the strategy:

1. gender equality in decision making and control over forest, trees and agroforestry resources and relevant value chains results in increased incomes and benefits for women;

2. the number of women newly empowered to plant and manage forests, agroforests and tree (FAT) resources in programme countries;

3. incomes from forest, trees and agroforestry goods and services controlled by women and men have increased such that gender inequality in income from these goods and services has decreased by at least $30 \%$;

4. at least $20-30 \%$ of women and their families have improved health conditions or have a reduced incidence of common illness due to nutritional deficiency in CRP6 programme countries;

5. $20-30 \%$ of members elected/appointed to forest management committees are women; and

6. $10-15 \%$ of women in programme areas have control (i.e., stronger rights) over FAT resources at household and community levels. 


\section{Goals and objectives}

CRP6 (see Box 1 below for a description of research programmes) is designed to make a significant contribution toward the vision and strategic objectives articulated in the CGIAR's Strategic Results Framework by:

- enhancing the contribution of forests, agroforestry and trees to production and incomes of forest-dependent communities and smallholders;

- conserving biodiversity, including the genetic diversity of trees, through sustainable management and conservation of forests and trees;

- maintaining or enhancing environmental services from forests, agroforestry and trees in multifunctional and dynamic landscapes;

- reducing emissions of greenhouse gases and augmenting carbon stocks through better management of forest- and tree-based sources

\section{Box 1. CRP6 research components}

1. The needs of smallholder producers, with emphasis on enhancing the productivity of trees on farm and improving smallholder access to markets for forest and tree products

2. The needs of forest managers at forest management unit level, with emphasis on improved technical and governance approaches to conserving forest ecosystems and their genetic resources

3. The needs of landscape-level planners and relevant stakeholders, with emphasis on mechanisms (such as payments for ecosystem services) for capturing the value of environmental services and for negotiating trade-offs among competing conservation and development objectives

4. The needs of policy makers and land managers seeking to include forests, trees and agroforestry in climate change adaptation and mitigation strategies

5. The needs of policy makers and land managers seeking to ensure that the impacts of globalised trade and investment flows are beneficial to forests and the communities that depend on forests for their livelihoods while increasing local and societal resilience through forest-, agroforestry- and tree-based adaptation measures; and

- promoting the positive impacts and reducing the negative impacts of global trade and investment as drivers of landscape change affecting forest lands, agroforestry areas, trees and the well-being of local people.

The CRP6 approaches gender integration as a crosscutting theme, which integrates gender analysis and research into each of the five components/research programmes. Gender analysis and research in the CRP6 seek to:

1. generate an understanding of key institutional, cultural and attitudinal contexts that entrench inequity across a relevant set of issue areas in the CRP6 research components, for example, adoption of technologies and practices, or participation and influence in decision making or knowledge and priorities;

2. identify policies, technologies and practices that will enhance gender equity in the access, use and management of forests and trees, and the distribution of associated benefits; and

3. offer guidance on how to avoid or mitigate negative impacts associated with relevant processes at multiple levels.

These three research goals will be achieved through four clusters of interrelated outcome categories that cut across the five CRP6 components (see Table 1 and Figure 1). These outcome categories are:

1. the knowledge, preferences and priorities of women (and men) are reflected across the relevant decision chains, including in the identification of research priorities;

2. the differential effects of policy processes, global or otherwise, including marketisation of forests and tree resources, on men and women are identified and mitigated;

3. the differential capacities to adopt materials, methods and knowledge are accounted for during interventions; and

4. the equitable participation in and influence over decision-making processes is enhanced. 


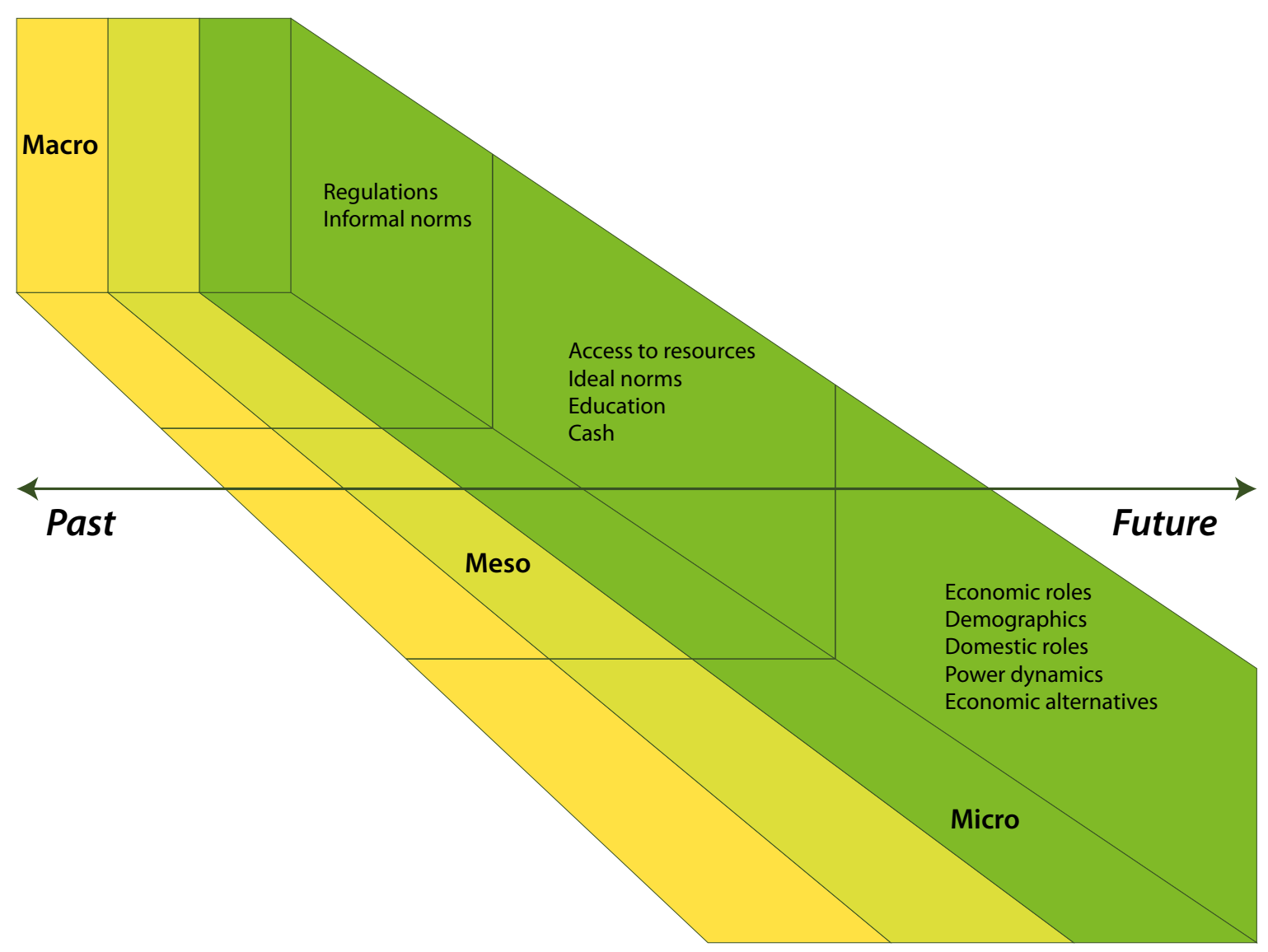

Figure 1. Gender box: A framework for the analysis and synthesis of gender in forest, tree and agroforestry systems

Table 1 illustrates the gender-related outcomes that cut across the five CRP6 components.

These outcomes target both practical and strategic gender needs and interests, and will form the basis for the CRP6-wide synthesis of gender-specific research results, lessons learned, and good practice. Frameworks to support hypothesis testing and synthesis across these categories will be developed in close consultation with the CGIAR CRP-wide gender network.

Gender-relevant research questions in the CRP6 are elaborated in Annex I. However, the following are some aspects of on-going gender-relevant research in the CRP6 research portfolio that capture recent trends.

Component 1: How can women's participation and bargaining power in NTFP (and other products) value chains be improved in order to reduce inequity in household benefits? What kinds of platforms can supply timely market information and feedback, especially to women?
Component 2: What are the preconditions for gender-equitable participation and benefits in forest rehabilitation and reforestation schemes? How can gender-specific knowledge be integrated into silvicultural practice?

Component 3: What are the gender-specific impacts of the implementation of payments for environmental services (PES) schemes? What approaches, including timing, sequencing and overall design of PES negotiation processes are necessary for ensuring gender-equitable and effective participation?

Component 4: What are the differential impacts of climate change and related initiatives in adaptation and mitigation on women's and men's tenure rights and livelihoods? How can climate negotiation and planning processes be structured, sequenced and timed to allow for the effective representation and/or participation of women and disadvantaged groups?

Component 5: How are benefits of (formal and informal) access and use of forest resources linked to global trade differentially distributed between men 
Table 1. Consideration of gender differentials and equality across the research components

\begin{tabular}{|c|c|}
\hline Theme & Issues across research components \\
\hline \multirow{4}{*}{$\begin{array}{l}\text { Knowledge, } \\
\text { preferences and } \\
\text { priorities reflected } \\
\text { in identification of } \\
\text { research topics }\end{array}$} & $\begin{array}{l}\text { Priorities for tree and forest species, traits, land uses } \\
\text { and products }(C 1-C 5)\end{array}$ \\
\hline & $\begin{array}{l}\text { Value chains and enterprise opportunities for tree } \\
\text { and forest products }(C 1, C 2)\end{array}$ \\
\hline & $\begin{array}{l}\text { Priority resources and mitigated impacts in climate } \\
\text { change adaptation }(\mathrm{C} 4)\end{array}$ \\
\hline & $\begin{array}{l}\text { Specific priorities of women: postharvest processing } \\
(\mathrm{C} 1, \mathrm{C} 2) \text {, bioenergy for household consumption (C4), } \\
\text { fruit trees }(C 2)\end{array}$ \\
\hline \multirow[t]{3}{*}{$\begin{array}{l}\text { Negative impacts } \\
\text { identified and } \\
\text { avoided/mitigated }\end{array}$} & $\begin{array}{l}\text { Trade-offs between land uses and livelihoods, } \\
\text { and displacement of user groups during forest } \\
\text { transitions (C3), market integration (C5), payments } \\
\text { for environmental services (PES) (C3) and REDD+ } \\
\text { projects (C4), and conservation actions (C2) }\end{array}$ \\
\hline & $\begin{array}{l}\text { Policies and strategies on tenure rights }(\mathrm{C} 1-\mathrm{C} 5) \text {, } \\
\text { ecosystem management }(\mathrm{C} 2, \mathrm{C} 3) \text {, REDD+ (C4), trade } \\
\text { and investment flows }(C 5) \text { and conservation (C2) }\end{array}$ \\
\hline & $\begin{array}{l}\text { Impacts of climate change (C4), loss of ecosystem } \\
\text { services (C3) and biodiversity (C2) on priority } \\
\text { systems, products and services }\end{array}$ \\
\hline
\end{tabular}

Differential access and ability to adopt materials, methods and knowledge accounted for in activities

Equitable participation in and ability to influence decision-making processes enhanced
Access to and control of land and tree resources during changing land uses, policies and markets (C1-C5)

Approaches and tools in ecosystem and tree management (C1-C3)

Approaches and tools in climate change adaptation and mitigation projects (C3)

Targeted extension and training approaches (C1-C4) Access to inputs, markets and market information on forest and tree products (C1, C5), PES (C3) and REDD+ (C4)

Obtaining and securing tenure rights during intensification (C1), forest transitions (C3), market integration (C5), development of markets for ecosystem services (C3) and REDD+ (C4), and conservation actions (C2)

Negotiation power on land uses and trade-offs with external actors: local and national authorities (C1-C5), market actors and industries (C1-C5), international climate policies (C4) and conservation NGOs $(C 2, C 3)$

Design of policies and strategies for tree and ecosystem management (C1-C3), PES (C3), climate change mitigation and adaptation (C4), trade, investment and land acquisition (C5) and conservation (C2)

Distribution of incomes from tree and forest products $(\mathrm{C} 1, \mathrm{C} 2, \mathrm{C} 5)$, PES (C3) and REDD+ projects (C4)

Reconciling needs and managing conflicts in resource use within households and communities (C1-C5)

\section{Key research strategies}

Participatory research and identification of topics

Sex-disaggregated data

Gender analysis for understanding the underlying factors

Participatory research and identification of topics

Sex-disaggregated data

Gender analysis for understanding the underlying factors

Knowledge sharing and tools development

Participatory research and identification of topics

Sex-disaggregated data

Gender analysis for understanding the underlying factors

Participatory scenario building and planning

Knowledge sharing and tools development

Outcome mapping

Participatory research and identification of topics

Gender analysis for understanding the underlying factors

Alliances built with policy and advocacy communities

Knowledge sharing and tools development

Sex-disaggregated data 
and women? What measures are needed to safeguard the rights of women and other vulnerable groups from large-scale commercial investments? What kinds of institutional arrangements are required to link measures and actions at the local level to national and transnational networks in order to make international trade and investment more accountable and cognizant of local-level differentiation and impacts?

While the four cross-cutting outcome categories mentioned earlier (knowledge and priorities, effects of policy processes, differential adoption, and participation and influence) are illustrative of some of the gender-relevant topics of concern for the CRP6, we have developed an analytical framework that will not only guide scientists and partners in their research work, but will also provide a sound basis for synthesising CRP6's 'gender story'. This gender framework summarises the range of gender-relevant variables in the social, political, economic and cultural domains (including scale and time horizon), as well as their interactions, and offers guidance for more systematic inquiry and action (Colfer, 2013: http://www.cifor.org/publications/pdf files/ OccPapers/OP-82.pdf). The 'gender box' illustrates our gender framework (Figure 1). 


\section{Impact pathways}

Social and political change can occur through multiple avenues, such as through improved knowledge and technology, collective organisation and mobilisation or contestation. Research and action in the CRP6 will make use of these various avenues for strengthening access of women and other disadvantaged groups to benefits and decision making in forest, tree and agroforestry research. The impact pathway in Figure 1 illustrates how the outputs and outcomes under each theme contribute to each other in achieving the outcomes. The achievement of this impact pathway is conditioned on a careful mix of research, advocacy, training and capacity building as well as on innovations in policy and practice. A series of partnerships and carefully crafted iterative processes are envisaged. For example, problem identification and research priorities will be established jointly with national-level partners, such as government ministries, university departments (e.g., Departments of Women and Gender Studies), and NGOs active in the forestry sectors at national and subnational levels. Representatives from each of these organisations will advise the research and action process, will review findings, identify entry points for policy and practice, and define possibilities and responsibilities for implementation. We anticipate that bringing in implementing actors at such an early stage will foster joint ownership, coproduction and joint responsibility for outcomes and learning.

Activities for transitioning from outputs to outcomes will include:

- collaboration with government ministries, NGOs and women's organisations;
- gender-differentiated cost-benefit analyses of impacts;

- awareness raising and capacity building for women and men; and

- the use of pilot projects to demonstrate the value addition of increased attention to gender.

Transforming outcomes to impacts will further include awareness campaigns; strategic communication of success stories; advocacy for equitable resource allocation and for the acquisition and securitisation of land or forest rights; and strengthening of women's forums. While CRP6 research teams will undertake global dissemination and outreach, all national-level partners will undertake the same among their networks and constituents at national level through workshops and advocacy campaigns.

To increase the likelihood of learning at each phase of the research cycle, the effectiveness of the interlinked processes leading to impacts will be monitored and evaluated (see the 'Monitoring and evaluation' section below for further details). However, the seeming linearity of the impact pathway may fail to reflect that single outcomes can have multiple impacts; that partnerships developed across multiple channels and governance levels can amplify impacts; or even that learning and feedback can prompt a rethinking of methodologies and problem analysis. The linear representation is illustrative (Figure 2). 


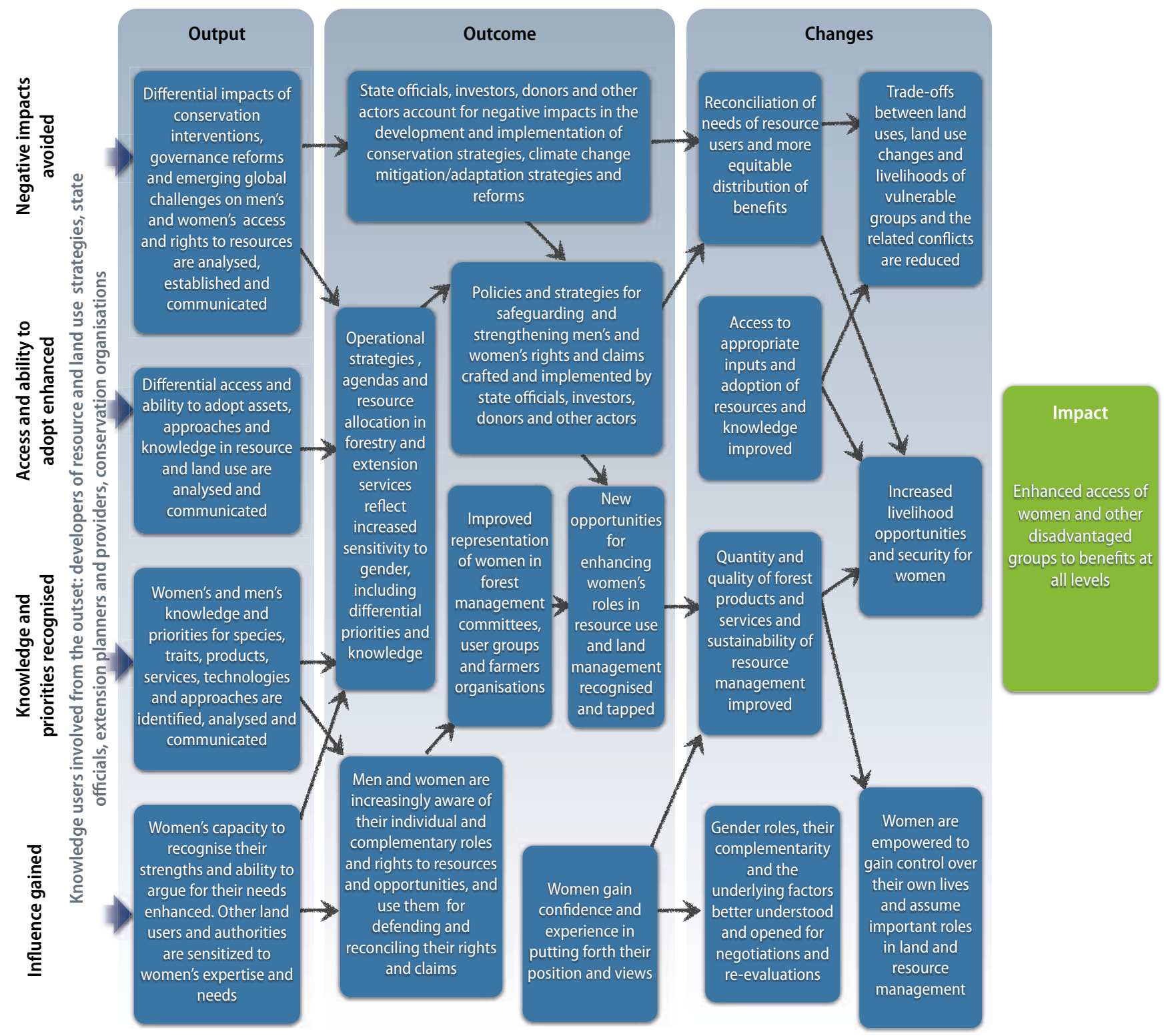

Figure 2. Gender impact pathway 


\section{Activities}

We deploy gender analysis methods, partnerships and alliances, knowledge sharing, and adaptive learning to effectively incorporate gender in the research cycle in CRP6. These approaches will be applied in combination at each phase of the research cycle for highest impact (Figure 3).

\section{A. Collection of sex- disaggregated data and gender analysis}

The regular and consistent gathering of sexdisaggregated data on various aspects of the forest, tree and people interface is mandated and nonnegotiable. Such data will help in identifying men's and women's differentiated perceptions, experiences, contributions and priorities; for example, during the targeting and priority setting phase of the research cycle. It will ultimately help in defining interventions that will enhance gender equity both at the levels of research design and when facilitating the adoption of outputs.

Researchers will consistently employ gender analysis as a tool to provide in depth information on gender differentiation, and, in particular, to identify institutional, cultural and attitudinal factors underpinning differentiation. Gender analysis will identify options and priorities for transforming inequality, and will identify the roles and responsibilities of relevant stakeholders in realising these options and priorities. Although gender differentiation is inherently a localised experience, the analysis of conditioning factors will highlight features of institutions (including markets, policies and legal regimes) at multiple governance levels that influence local-level outcomes (research design).

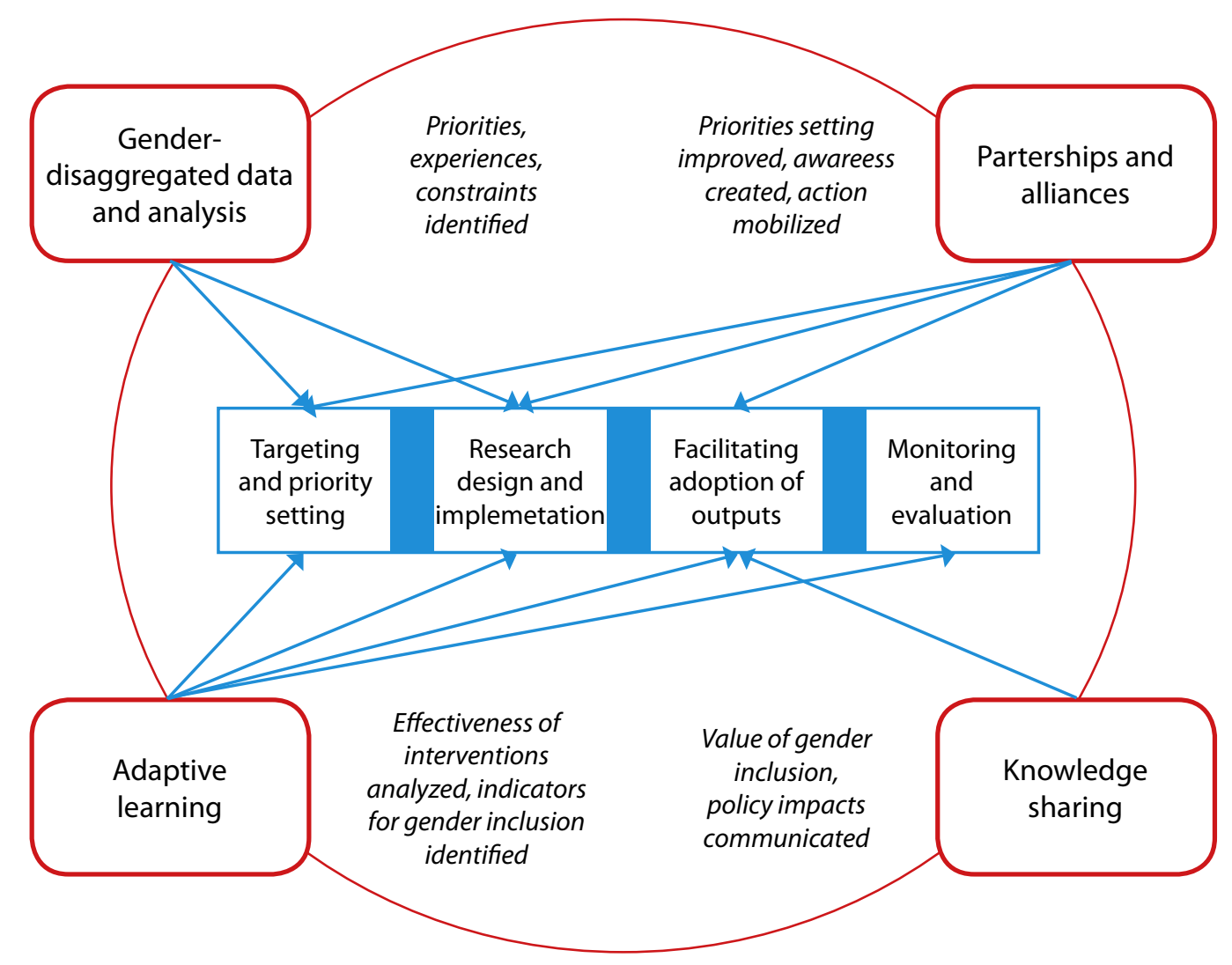

Figure 3. Approaches for achieving gender inclusion (red boxes) at each phase of the research cycle (blue boxes) 
Participatory approaches are well suited for enhancing inclusiveness, especially of disadvantaged groups, to allow better representation of multiple views, which improves people's capacity to act on their own behalf and to promote learning. We will pursue multiple methodologies to generate insights into the gender-relevant policy problems and core research questions identified in each component of CRP6. Quantitative household surveys will be used to establish household-level effects and responses. Intra-household surveys will be encouraged in line with recent advances in gender research that demonstrate that preferences, resources and overall access can differ between men and women within households. Experimental games may be used to facilitate the isolation and analysis of specific variables of interest. However, we will place a premium on the application of participatory techniques that hold great promise for inclusion, learning and empowerment. (Note that participants at the Javana CRP6 gender methods workshop endorsed participatory techniques but pointed out several downsides that needed to be taken into account from the outset such as the possibility that participation may mask power relationships or even burden men and women further.) Adaptive Collaborative Management, which combines a series of participatory techniques for problem identification and resolution such as participatory action research, focused group discussions, transect walks, participatory mapping and outcome mapping, will form a methodological pillar for gender analysis in CRP6. We will add an historical dimension to our analysis in order to illustrate the dynamic nature of how women may gain or lose authority in the use and management of and control over forest and trees and their products and services. For an historical analysis of gendered access to markets, see Wardell and Fold (in press).

Because the nature and magnitude of gendered outcomes may vary depending on cultural and social norms, research will be conducted in different settings. Each CRP6 component has not only identified specific gender-related research questions (see Annex I for a detailed listing of gender research questions per component), but has also identified geographic priorities, spanning Africa, Asia and Latin America, where culture and social norms may differ. Moreover, sentinel landscapes, which will be established in diverse settings, provide an opportunity for monitoring change and assessing impacts of specific policy interventions and/or practices. Data collection methodologies will be both qualitative and quantitative and data analysis will range accordingly from statistical techniques (including regressions) to interpretation of norms, conventions and practices to identify the underlying mechanisms that lead to visible actions and outcomes.

Component and project leaders will encourage multidisciplinary research teams-comprising both male and female researchers - to work with both men and women. Training programs and workshops will enable CGIAR centre researchers and their partners to shift from collecting sex-disaggregated data to comprehending the dynamics of gender relations. Training sessions and workshops will be conducted at least once per year and will be targeted at building analytical skills, increasing exposure to the range of data gathering methods and types of research questions, building targeted partnerships for impact, and sharing good practice (note that a Gender methods manual/toolkit has been developed for researchers and partners, which is accompanied by an Occasional Paper on methods for more advanced users (Manfre and Rubin, 2012: http://www.cifor. org/publications/pdf files/Books/BCIFOR1203.pdf; Colfer and Minarchek, 2012: http://www.cifor.org/ publications/pdf files/OccPapers/OP-80.pdf)). These are available in English, French, Spanish and Bahasa Indonesia. Emphasis will be placed on disaggregating the generalised categories of 'men' and 'women', in order to capture other salient attributes such as wealth, ethnicity, age, religion, and marital status, which may also drive differentiation, depending on the social and political setting (research design and implementation).

\section{B. Partnerships and alliances to enhance gender inclusiveness}

Since gender inequality is rooted in societal relationships, broad changes are necessary for closing or narrowing the gender gap. Research teams will build alliances with both policy and advocacy communities, within and across sectors and across governance levels, to ensure the adoption of research outputs and improve impacts. Strengthening links to advocacy networks and platforms (including media and women-focused civil organisations) is critical for raising awareness of gender-related issues and for mobilising action toward gender inclusion (facilitation of adoption of outputs). Moreover, these links will increase the likelihood that problem 
identification and prioritisation are gender-sensitised (targeting and priority setting).

On the research front, we will seek to partner with the International Center for Research on Women (ICRW). Researchers will also explore opportunities for learning among peers in the CGIAR network and with other CRPs such as CRP2 where gendered rights and access to natural resources, gendered resource management and gendered access to markets are prominent themes (research design, monitoring and evaluation).

At national and supranational levels, current partnerships will be strengthened and new ones sought with women's farming or forest organisations, forest users' federations, women-focused civil society organisations and local media. Partnerships with the Food and Agriculture Organization of the United Nations, International Fund for Agricultural Development and the International Land Coalition will provide further opportunities for creating and strengthening contacts with local organisations. The governments of many developing countries have established gender or women's ministries and departments; we will seek to partner with them in addition to gender sections in forestry and agriculture ministries. Similarly, national universities are increasingly establishing departments of gender and/or women's studies. Specific attention will be paid to creating opportunities and encouraging partnerships between the various partners of the CRP6 and gender-specific organisations. Such networks will strengthen the women's organisations (especially at national and local levels), allow identification of complementarities and enhance the uptake and adoption of research outputs (research design and implementation, facilitation of adoption of outputs).

At the international level, cooperation will be strengthened with FAO's Gender Program, IFAD, ILC, Women Organizing for Change in Agriculture and NRM (WOCAN) and The World Conservation Union (IUCN). These organisations have strong links with regional and national networks that provide advocacy for gender equity in resource use planning, policy formulation, access to resources and information and benefit sharing. We will also seek to build partnerships with the newly mandated UN WOMEN (facilitation of adoption of outputs).

\section{Knowledge sharing for gender-responsive policy and practice}

The third step (closely related to the second) will include systematic documentation and dissemination of knowledge generated through gender-responsive research. Such documentation will include good practice guides, training guides, policy briefings and scientific articles spanning different aspects of gender in forest, tree and agroforestry use and management. Documentation will articulate the interconnections between new behaviours and success and will provide insights into how changes promoting gender equity can be embedded into ongoing structures and practices.

Research teams will regularly share findings among CRP6 researchers, communities, practitioners and policy makers to become and remain informed about the importance of supporting gender equitable practices to enhance both the productivity and sustainability of forest resources. Such dissemination will continuously clarify the value addition of gender and reinforce attention to gender perspectives (facilitation of adoption of outputs). In addition to this strategy document and research results, products completed in 2012 included works on methods and a conceptual framework. In 2013, additional products will document key research findings across world regions, synthesising what is known about genderbased constraints related to forest management and group governance, and "good practices" to overcome or reduce them. The CRP6 Gender focal points will work with the different Centers' communication teams to prepare an annual calendar of events at which time gender research-related materials would be appropriately disseminated. For example, preparing an overview of research results for publication coinciding with International Women's Day annually on 8 March or preparing a blog about gender and forestry issues in preparation for World Forest or Agriculture Day. Concerted efforts will be made to identify important outlets that can further disseminate the results of CIFOR gender-related research to other gender specialists. Other social media will also be utilised, e.g, Twitter, Twitter chats, Facebook and blog posts. 


\section{Adaptive learning for gender- responsive research and analysis}

Researchers will develop and track indicators to capture inclusion, to improve gender equity, to evaluate the effectiveness of programmes, projects and interventions, and to improve data collection and analysis systems. These indicators will span the breadth of forestry and agroforestry concerns; including, representation in planning and decisionmaking processes, property rights, access to technologies and services, income distribution, market access and innovation systems. We will select and apply appropriate quantitative and qualitative indicators to assess and communicate the true magnitude of impacts. Such assessments will allow for a critical analysis of activities and outputs and for the incorporation of new knowledge into existing and anticipated phases of research (targeting and priority setting to monitoring and evaluation). See the section 'Monitoring and evaluation' for further details. 


\section{Capacity for gender research and analysis}

The CRP6 approaches gender integration as a crosscutting theme, which seeks to integrate gender analysis and research questions into each of the five components, rather than have a specific, isolated component that is focused only on gender. A crosscutting thematic approach demands a high level of involvement and a higher capacity for gender analysis, research and reporting among scientists. Consequently, the CRP6 gender theme will initially focus on building capacity for gender analysis and research, to boost the capabilities of components and will be the main avenue through which scientific, conceptual and methodological leadership and coordination is provided towards integrating gender concerns in research. Because leadership will eventually transition to the component leaders (from the gender focal points) as knowledge and skills for gender integration are more broadly acquired and practised by scientists, our capacity-building initiatives will also target those science managers and leaders who are mandated with team building and overall science direction.

Currently, the CRP6 gender theme covers up to $20 \%$ of the contribution of three senior scientists, in three participating centres as well as 10\% of the CRP6 director's time. Over the next 3 years, the gender theme will recruit four postdoctoral fellows at 100\% of their time.

Capacity for gender analysis and research in the CRP6 is uneven within and across participating centres (see Table 2). At CIFOR, only approximately 17 scientists (16 at The World Agroforestry Centre, ICRAF) have the capability to conduct gender-responsive research. These individuals are currently implementing various aspects of genderresponsive research and action, from the collection of gender-disaggregated data to gender analysis and reporting. Several have published gender-focused papers in the past 2 to 4 years. At CIFOR, most of this capability is concentrated in two research components: Component 1 (Smallholder producers) and Component 4 (Climate change adaptation and mitigation), drawing scientists from the Forests and Governance and Forests and Livelihoods Programs.

Overall capacity for gender analysis and research is concentrated. In CIFOR, for example, out of a total of 79 science staff, only 26 are social scientists

Table 2. Capacity for gender research and analysis in the CRP6

\begin{tabular}{llccl}
\hline & & PhD & Masters & Level of gender analysis and knowledge \\
\hline Scientist & CIFOR & 8 & 4 & High \\
& ICRAF & 8 & & Medium to low \\
& Bioversity & $(1)^{*}$ & 1 & Medium to low \\
Associate & CIFOR & 4 & & Very high \\
& ICRAF & & 6 & Medium to low \\
Postdoc & CIFOR & 1 & & Low \\
& ICRAF & 1 & & High \\
\hline Total & & 22 & 10 & \\
\hline Consultant & CIFOR & 1 & 1 & Very high \\
& ICRAF & 1 & & High \\
& Bioversity & 1 & & Very high \\
\hline
\end{tabular}

CIFOR: 17 individuals, 2 non-social scientists $=15$ social scientists

ICRAF: 16 individuals, 2 non-social scientists $=14$ social scientists

Bioversity: 2 individuals, 1 social scientist, 1 non-social scientist; 1 social scientist to join in early 2013

TOTAL $=35$ 
(excluding associates and consultants). Of the 26 social scientists, 11 have some capacity for gender integration and only 10 can be termed as having a high level of capacity with both the capability of collecting sex-disaggregated data, performing gender analysis and reporting on it. For CIFOR, because this capacity is concentrated in two research components (i.e., climate change and smallholder producers), and not across all five research components, there is currently a capacity gap. This holds true for all centres participating in the CRP6. At the initiation of the CRP in 2011, Bioversity International's Forest Genetic Resources (FGR) Programme did not have social scientists with gender research expertise. A scoping study was commissioned in 2012 to assess opportunities and approaches for integration of gender analysis and gender research in the research programme. Following the recommendations of the scoping study, Bioversity will recruit a gender specialist in 2013 to work full time with the FGR Programme and the CRP. In addition, Bioversity will announce three to four gender research fellowships in 2012 and 2013 to support integration of gender considerations in ongoing and new research of the FGR Programme. Over the short and medium term, capacity will be increased and strengthened in various ways: i) recruitment (up to four gender specialists at the $\mathrm{PhD}$ level will be hired in the first 2 years of the CRP6); ii) training of current scientists; and iii) targeted deployment of gender-specialist consultants. We anticipate that these efforts will pay off over the longer term leading to at least a doubling of current capacity. In addition, and in consultation with human resources and centre management committees, we envisage that recruitment processes for social science positions will incorporate and assess for gender integration capabilities.

Thus we place a premium on building capacity among researchers and their partners in various ways. Since the start of the CRP6, three training workshops in gender concepts and analysis have been delivered for a total of 125 researchers, managers and partners. At least 1 training session per year will be conducted for the next 3 years, and will be varied to target different thematic interests and levels of knowledge. Annual self-assessment and reviews among scientists will be encouraged; however, we plan to conduct training needs assessments every third year to capture emerging issues and to assess advancement toward gender literacy.
Materials to support scientists in analysis and reporting on their gender research are an important part of our capacity-building programme. Annotated bibliographies, illustrated methods guides and manuals, and tools, translated into different languages, will be available both in print and electronically on the CRP6 website within the first year and will be updated annually. In addition, syntheses and reviews of key thematic issues such as participation, knowledge, bridging research and policy, women's leadership, gender dynamics along the forest transition curve, etc. will be produced in the first 1-2 years of the programme in order to provide scientists and research partners with state-ofthe-art thinking and information on these key issues. Capacity building activities will be coordinated with the CGIAR gender network to add value and to leverage resources and capability across CRPs.

Each participating centre faces unique opportunities and constraints. We thus adopt a flexible approach to the implementation of the gender strategy in response to these specificities. For example, while all centres prioritise training and mentorship, and the joint design of training tools and instruments, each centre will deliver the training programme based on the level of scientists' knowledge and skills. Moreover, centres will follow their own approaches for building and sustaining partnerships to support gender research and action. This also allows for experimentation with knowledge to action linkages, the identification of good practice, the sharing of it and eventual adoption CRP6-wide.

Linkages with the AWARD programme will be created to access women's leadership courses to increase women's leadership in the workplace, as well as with other CRP gender programmes in addressing key gender questions that cut across CRPs. The gender capacity building programme will include such elements as individual centre- and CRP6-level workshops, seminars, conferences, training sessions for women's leadership, methods and indicators development, and exchange visits. The programme will also include mentoring of young gender scientists and investments in postdoctoral fellowships to attract bright young men and women into gender research. A succession plan for gender research must also be included to ensure that trained gender scientists are recognised and rewarded so as to sustain institutional capacity of gender-responsive research. 


\section{Monitoring and evaluation}

CRP6 has developed a Monitoring Evaluation and Impact Assessment (MEIA) strategy that frames our approach to MEIA. We have produced seven draft Intermediate Development Outcomes (IDOs), to be finalised in 2013, allowing us to monitor and assess our progress in achieving the System Level Outcomes. Although six of these IDOs are relevant to gender, we have crafted one specific IDO that captures the end-goal of our investments in gender integration in research and action:

\footnotetext{
'Women are better empowered and gender equality in decision making and control over resource use, management and benefits is improved'.
}

We will monitor gender integration at three levels:

1. Gender integration processes. This will focus on identifying the effectiveness of the process elements of delivery, for example, whether training and capacity-building initiatives are relevant; whether the mechanisms of delivery are responsive to differences in knowledge, skills and thematic interests; component needs and outputs; whether gender-relevant knowledge and skills are being built; and whether a congenial atmosphere for gender research support has been established. This will draw heavily from scientists and partners' self-evaluations and feedback.

2. Outputs. This will determine whether our strategy and approach to gender integration in research and action is effective in changing scientists' behaviour. We will track and measure the following aspects:

- the extent to which gender is incorporated into new proposals, bearing in mind that not all subject matter is amenable to gender analysis. Gender guides for proposal development and assessment will be developed that provide concrete examples of how the following elements of our strategy will be taken into account in methods, activities and budgets:

- collection of gender-disaggregated data

- application of gender analysis

- inclusion of gender-relevant delivery partners

- gender-responsive knowledge sharing
We place emphasis on the proposal stage because gender is most effectively incorporated at the research design stage with the identification of research questions and the subsequent identification of methods, activities, personnel and budgets.

- the extent to which research outputs produced by components:

- are based on sex-disaggregated data sets and the extent to which the definition of target populations accounts for gender disparities

- employ gender analysis

- are co-produced with gender-specialised partners

- are disseminated to reach relevant networks and actors, including feedback to communities explaining findings and how information can be used including possible follow-up actions

- influence policy, practitioners, or resource users' knowledge and/or actions

3. Impact analysis. This will focus on project sites and sentinel landscapes to establish the extent to which gender-responsive research has achieved the CGIAR system's strategic results of poverty reduction, enhancing food security, improving health and nutrition, and environmental sustainability. For example, participants at the Javana gender methods workshop indicated that: i) the strategy should allow for the tracking of unexpected/unintended outcomes; and ii) impact analysis should be explicit about the stories behind any change, noting in particular that although some changes may occur, they may not be easily measurable. We will focus on tracking the following impacts:

- Gender equality in decision making about and control over forests, agroforestry and tree resources and relevant value chains results in increased incomes and benefits for women.

- Women's increased control over forests, agroforestry and tree resources enhances family nutrition and health.

- More secure tenure and rights for men and women increase access to diversified and improved food and tree species/varieties. 
- Gender equality in participation and influence over resource use decisions and benefits increases investments in sustainable resource management and reduces degradation.

This three-tier monitoring and evaluation plan reflects the procedural and substantive elements of our impact pathway. It articulates a framework for monitoring and evaluating progress towards gender integration/implementation of this gender strategy and more broadly accomplishing the genderspecific aims of the CRP6. As discussed below, it will include internal, continued self-assessments which will contrast planned activities with results. It also includes independent, periodic, and strategic assessments.

\section{Implementing the monitoring and evaluation plan}

This plan will be implemented through existing organisational structures and processes.

Each capacity-building programme will be required to administer a standard evaluation form that will be jointly designed by gender focal points at participating centres. Post-training evaluations are commonly administered to all participants. In addition, the number and type of requests for gender analysis support made by both scientists and their partners, as well as the number of downloads of gender materials on the CRP6 (and centre) website will be tracked.

Gender integration at the proposal stage will be monitored through the donor liaison's office in the finance and administration department. A dedicated database, which will capture specific information on gender integration in key elements of the proposal, will be queried and analysed once a year. The aim is to increase the number of research proposals integrating gender in research questions, activities and budgets, keeping in mind that some proposals may not necessarily or feasibly address gender matters.

The monitoring of research outputs will be conducted by gender focal points, who will maintain a central database at ICRAF of existing research projects and outputs. This will be closely coordinated with component leads and the Information Services Group of each centre and will be conducted once each year. The aim is to track changes in the number of outputs that a) collect gender-disaggregated data; and b) systematically analyse and explain trends patterns.

Results of the above will be shared with scientists at annual meetings/science weeks scheduled by each centre every September/October. CIFOR, for example, schedules a gender technical session at each annual meeting. This provides a forum for encouraging dialogue on accomplishments and constraints, how gender integration efforts might be improved, and what further support will be needed in the following year. These forums will be supplemented by targeted focused group discussions and short surveys in order to generate deeper insights into successes, constraints and improvement measures.

Impact evaluation will be closely coordinated with the Monitoring, Evaluation and Impact Assessment team of the CRP6, which has developed principles to guide the process and for which the organisation has ring-fenced a budget line within each research proposal. The Monitering \& Evaluation (M\&E) task force of the CGIAR Gender Network will provide additional support to impact evaluation. However, we will also encourage scientists to build into their research and implementation, a monitoring and evaluation scheme. This is currently being implemented by the 'Gender, tenure and community forestry in Uganda and Nicaragua' project funded by the Austrian Development Agency and will be used to inform CRP6 gender MEIA efforts. Withinproject monitoring allows for the monitoring and evaluation of immediate outcomes (changes in behaviour of resource users or policy makers; improvements in knowledge), which can be collected at shorter time periods such as annually or twice per year. We anticipate that longer term impacts (changes in key indicators specified) will be evaluated at least twice in the 10-year life of the CRP6. Besides standard evaluation of specified indicators, impact evaluations will identify the following:

- short and longer term risks and their mitigation

- necessary adjustments to gender research and implementation by delivery partners, including budget implications

- lessons learnt and how to distill good practices in research and implementation

Feeding the findings of impact evaluation back to researchers and practitioners will be given priority. We will use existing channels commonly used for 
sharing information among scientists and with policy makers and practitioners. These include annual meetings and targeted communications to partners such as partner networks/distribution lists, policy briefs, and international forums such as CIFOR's annual Forest Days and ICRAF's Agriculture/ Biodiversity Day.

Indicators, frequency of collection and collection methods have been summarised (Table 3). A major shortcoming is that these indicators are mostly quantitative. However, we will employ qualitative indicators that speak to mechanisms and interlinkages. For example, the institutional conditions that allow for increased numbers of women in decision-making positions will be documented.

Incentives to encourage successful gender integration will be jointly negotiated between managers and scientists during the annual performance appraisal process. Possible incentives include supplemental funding, targeted training and presentations at international forums as well as showcasing effective integration efforts in the outcome stories of annual reports.

\section{Budget presentation}

About $10 \%$ of the CRP 6 component budget (excluding the gender cross-cutting theme) is dedicated to gender research and analysis (Table 4).

These figures are indicative, based on our Performance Implementation Agreement for the cross-cutting themes and on the rolling 3-year operational plan for gender-relevant research within components. They are in our current operational plan (OP 2012-2014) and must be considered estimates. The next iteration of the plan (OP 2013-2015) will have more reliable figures accompanied by a specific annual programme of work. The gender cross-cutting theme has a separate budget of USD 3427711 over the same time period.

\section{Management system}

The gender cross-cutting theme is under the supervision of the CRP 6 director and this theme and associated activities are coordinated by a gender coordinator, with focal points in each of the participating centres (i.e., CIFOR, ICRAF, Bioversity, CIAT. The CRP6 director is designated with oversight of the management and budgets of the cross-cutting gender theme. Centre gender 'focal points' (CIFOR, ICRAF, Bioversity, CIAT) report to the gender coordinator. Gender focal points from each centre form a working group to support gender analysis and ensure that gender issues are addressed in all activities of CRP6 in line with the gender strategy. They will develop criteria for assessing analytical work and conduct quality assurance reviews. They will build a CRP6-wide approach to gender integration, but each of them will also participate in various capacities in a cross-CGIAR gender network for guidance, support and sharing of good practice.

Rotational leadership/coordination is applied to ensure that responsibilities and opportunities are shared amongst the focal points from each centre during the strategy period. Annual work plans are planned openly and shared amongst the focal points; joint centre activities will be also encouraged to build collaboration and collective action in achieving gender-responsive goals and objectives. Semi-annual and annual reports from focal points are required, and are reported to the gender coordinator and ultimately to the CRP6 director.

At centre level, the focal points are responsible for implementing annual work plans with reporting responsibilities both to the CRP6 gender coordinator and to centre management, respectively. Centres may have different structures for implementing gender cross-cutting activities as well as gender research in the components, but the idea of creating 'Gender Implementing Teams' (GITs) is being considered. The GITs, headed by the centre focal point will then be responsible for ensuring delivery of gender-responsive goals and objectives of the CRP components. With the right capacity and support, the GITs can evolve into a formal feature of the CRP6 management and operational structure.

While it may appear as though a disproportionate share of the responsibility for gender integration is concentrated in gender focal points and the CRP6 director, the responsibility is broader and embedded in centre management and operational structures and processes. Component leaders, who took the lead role in identifying gender-relevant research questions (see Annex I), and who have allocated close to $10 \%$ of component budgets to gender-related research and action activities, have a responsibility to ensure that component research and research outputs are reflective of this investment. Similarly, programme directors (who bear overall responsibility for science 
Table 3. Summary of monitoring and evaluation plan

\begin{tabular}{|c|c|c|c|c|}
\hline $\begin{array}{l}\text { What will be } \\
\text { monitored? }\end{array}$ & Indicators & $\begin{array}{l}\text { Data collection } \\
\text { methods }\end{array}$ & Frequency & Responsibility \\
\hline \multirow{2}{*}{$\begin{array}{l}\text { Gender } \\
\text { integration } \\
\text { process }\end{array}$} & $\begin{array}{l}\text { Percentage of projects generating } \\
\text { gender-disaggregated data }\end{array}$ & Database search & Annual & Gender focal points \\
\hline & $\begin{array}{l}\text { Number of projects that use gender- } \\
\text { disaggregated data for targeting } \\
\text { and priority setting }\end{array}$ & & & \\
\hline $\begin{array}{l}\text { Gender } \\
\text { integration } \\
\text { process }\end{array}$ & $\begin{array}{l}\text { Number of scientists and partners } \\
\text { trained }\end{array}$ & $\begin{array}{l}\text { Participants list and } \\
\text { surveys }\end{array}$ & Annual & Gender focal points \\
\hline $\begin{array}{l}\text { Gender } \\
\text { integration } \\
\text { process }\end{array}$ & $\begin{array}{l}\text { Number of scientists and partners } \\
\text { taking advantage of mentoring } \\
\text { programmes }\end{array}$ & $\begin{array}{l}\text { Participants list and } \\
\text { surveys }\end{array}$ & Annual & Gender focal points \\
\hline \multirow[t]{3}{*}{$\begin{array}{l}\text { Gender } \\
\text { integration } \\
\text { process }\end{array}$} & $\begin{array}{l}\text { Percentage of projects with } \\
\text { monitoring and evaluation } \\
\text { components/indicators }\end{array}$ & Database search & Annual & Gender focal points \\
\hline & $\begin{array}{l}\text { Whether targeting addresses gender } \\
\text { differentiation }\end{array}$ & & & \\
\hline & $\begin{array}{l}\text { Whether priority setting for research } \\
\text { planning included gender-related } \\
\text { criteria }\end{array}$ & & & \\
\hline Outputs & $\begin{array}{l}\text { Number of reports/policy briefs/ } \\
\text { InfoBriefs that are based on gender- } \\
\text { disaggregated data and gender } \\
\text { analysis }\end{array}$ & Reading reports & Biennial & $\begin{array}{l}\text { Gender focal points; } \\
\text { Component leaders }\end{array}$ \\
\hline Outputs & $\begin{array}{l}\text { Number of partners using/referring } \\
\text { to gender-related information in } \\
\text { reports, policy briefs, etc. }\end{array}$ & $\begin{array}{l}\text { Scientist self-evaluation; } \\
\text { surveys }\end{array}$ & Biennial & $\begin{array}{l}\text { Gender focal points; } \\
\text { Component leaders }\end{array}$ \\
\hline Outputs & Changes in capacity of partners & $\begin{array}{l}\text { Scientist evaluations; } \\
\text { surveys of partners }\end{array}$ & Biennial & $\begin{array}{l}\text { Gender focal points; } \\
\text { Component leaders }\end{array}$ \\
\hline Impacts & $\begin{array}{l}\text { Income from } \text { FAT }^{1} \text { goods and } \\
\text { services controlled by women and } \\
\text { men has increased such that gender } \\
\text { inequality in income from these } \\
\text { goods and services has decreased } \\
\text { by at least } 30 \%\end{array}$ & Surveys & $3-5$ years & $\begin{array}{l}\text { CRP6 director; CRP6 } \\
\text { MEIA team; Gender } \\
\text { focal points }\end{array}$ \\
\hline Impacts & $\begin{array}{l}\text { At least } x x \text { women and their families } \\
\text { benefit from FAT products for food } \\
\text { security for xx additional days during } \\
\text { the dry season }\end{array}$ & Surveys & $3-5$ years & \\
\hline Impacts & $\begin{array}{l}20-30 \% \text { of members elected/ } \\
\text { appointed to forest management } \\
\text { committees are women }\end{array}$ & Surveys & $3-5$ years & \\
\hline Impacts & $\begin{array}{l}10-15 \% \text { of women in programme } \\
\text { areas have control (i.e., stronger } \\
\text { rights) over FAT resources at } \\
\text { household and community levels }\end{array}$ & Surveys & $3-5$ years & \\
\hline
\end{tabular}

1 Forest, Agroforestry and Tree resources 
Table 4. CRP6 gender budget

\begin{tabular}{lccc}
\hline & CRP 6 Annual budget for gender research and analysis by component and year \\
\hline Gender & $\mathbf{2 0 1 2}$ & $\mathbf{2 0 1 3}$ & 2014 \\
C1 & 1161272 & 1411628 & 1665143 \\
C2 & 943342 & 1095691 & 1190840 \\
C3 & 1289598 & 1586500 & 1866892 \\
C4 & 3176911 & 3362517 & 3573243 \\
C5 & 546364 & 624323 & 690340 \\
\hline TOTAL & $\mathbf{7 1 1 7 4 8 7}$ & $\mathbf{8 0 8 0 6 5 9}$ & $\mathbf{8 9 8 6 4 5 8}$ \\
\hline Cross-cutting gender & 906604 & 1309573 & 1211535 \\
\hline
\end{tabular}

direction and budget allocations) review research proposals and appraise scientist performance annually and bear responsibility for gender integration in programmes and in the science. The yearly performance appraisal processes provide an as yet untapped and promising avenue for the diffusion of responsibility to individual scientists. Finally, centre boards of trustees have a responsibility for ensuring that a centre's science and management goals and strategies are achieved in an effective and rigorous manner.

Overall, this strategy views gender integration in research as a fundamental part of doing good science (and development). The success of this strategy rests on embedding gender integration in processes and structures that animate each centre's science. 


\section{References}

Acharya, K.P. and Gentle, P. 2006. Improving the effectiveness of collective action: sharing experiences from community forestry in Nepal. CAPRi Working Paper No. 54. International Food Policy Research Institute, Washington, DC.

Agarwal, B. 2001. Participatory exclusions, community forestry, and gender: An analysis for south Asia and conceptual framework. World Development 29(10):1623-48.

Agarwal, B. 2007. Gender inequality, cooperation, and environmental sustainability. In: Baland, J.M., Pranab, B., and Bowles, S. (eds.) Inequality, cooperation, and environmental sustainability, 274-313. Princeton, New Jersey: Princeton University Press.

Agarwal, B. 2009. Gender and forest conservation: The impact of women's participation in community forest governance. Ecological Economics 68(11): 2785-99.

Agrawal, A. and Chhatre, A. 2006. Explaining success on the commons: community forest governance in the Indian Himalaya. World Development 34(1): 149-66.

Carr, M., and Hartl, M. 2008. Gender and nontimber forest products: promoting food security and economic empowerment. International Fund for Agricultural Development (IFAD), Rome, Italy.

Coleman, E., and Mwangi, E. 2013. Women's participation in forest management: a crosscountry analysis. Global Environmental Change. 23(1): 193-205.

Colfer, C. (ed). 2005. The equitable forests: diversity, community and resource management. Resources for the Future, Washington, DC.

Colfer, C.P. and Minarchek, R.D. 2012. Women, men and forest research: A review of approaches, resources and methods for addressing gender. Occasional Paper 80. CIFOR, Bogor, Indonesia. http://www.cifor.org/publications/pdf_files/ OccPapers/OP-80.pdf

Colfer, C.J. 2013. The gender box: A framework for analysing gender roles in forest management. Occasional Paper 82. CIFOR, Bogor, Indonesia. http://www.cifor.org/publications/pdf_files/ OccPapers/OP-82.pdf.
Crewe, E. and Harrison, E. 1998. Whose development?: An ethnography of aid. London: Zed Books.

Engle, P.L. 1993. Influences of mothers' and fathers' income on children's nutritional status in Guatemala. Social Science and Medicine 37(11):1303-12.

Ferrier, S. 2002. Mapping spatial pattern in biodiversity for regional conservation planning: where to from here? Systematic Biology 51:331-63.

German, L. et al. 2008. Enabling equitable collective action and policy change for poverty reduction and improved natural resource management in the eastern African highlands. CAPRi Working Paper No. 86. International Food Policy Research Institute, Washington, DC.

Hoddinott, J., and Haddad, L. 1995. Does female income share influence household expenditures? Côte d'Ivoire. Oxford Bulletin of Economics and Statistics 57(1): 77-96.

Howard, P.L. and Nabanoga, G. 2007. Are there customary rights to plants? An inquiry among the Baganda (Uganda), with special attention to gender. World Development 35(9): 1542-63.

Kennedy, E. and Peters, P. 1992. Household food security and child nutrition: the interaction of income and gender of household head. World Development 20(8): 1077-85.

Kiptot, E., and Franzel, S. 2012. Gender and agroforestry in Africa: a review of women's participation. Agroforestry Systems 84: 35-58.

Komarudin, H. Siagian, Y.L. and Colfer, C.J.P. with Neldysavrino, Yentirizal, Syamsuddin and Irawan, D. 2008. Collective action to secure property rights for the poor: a case study in Jambi Province, Indonesia. CAPRi Working Paper No. 90. International Food Policy Research Institute, Washington, DC.

Lemenih, M., Abebe, T. and Olsson, M. 2003. Gum-resins from some Acacia, Boswellia and Commiphora species and their economic contributions in Liban zone, Ethiopia. Journal of Arid Environments 55: 465-82.

Manfre, C. and Rubin, D. 2012. Integrating Gender into Forestry Research: A Guide for CIFOR 
Scientists and Programme Administrators. CIFOR, Bogor, Indonesia. http://www.cifor.org/ publications/pdf_files/Books/BCIFOR1203.pdf

Mai, Y.H., Mwangi, E. and Wan, M. 2011. Gender analysis in forestry research: looking back and thinking ahead. International Forestry Review 13(2): 245-58.

Meinzen-Dick, R., Quisumbing, A., Behrman, J., Biermahyr-Jenzano, P., Wilde, V., Noordeloos, M., Ragasa, C., Beintema, N. 2010. Engendering agricultural research. Paper to Global Conference on Agriculture and Rural Development. Montpellier, France, 28-31 March.

Mwangi, E., Sun, Y. and Meinzen-Dick, R. 2011. Gender and sustainable forest management in East Africa and Latin America. Ecology and Society 16(1): 17. http://www.ecologyandsociety. org/vol16/iss1/art17/

Place, F. 1995. The role of land and tree tenure on the adoption of agroforestry technologies in Zambia, Burundi, Uganda, and Malawi: a summary and synthesis. Land Tenure Center, University of Wisconsin, Madison, WI.

Quisumbing, A.R., Payongayong, E., Aidoo, J. B. and Keijiro Otsuka, K. 2001. Women's land rights in the transition to individualized ownership: implications for tree-resource management in Western Ghana. Economic Development and Cultural Change 50: 157-81.
Ruiz Perez, M., Ndoye, O., Eyebe, A., and Lema Ngono, D. 2002. A gender analysis of forest product markets in Cameroon. Africa Today 49(2): 97-126.

Shanley, S. and Gaia, G.R. 2001. Equitable ecology: collaborative learning for local benefit in Amazonia. Agriculture Systems 73: 83-97.

Smith, L.C., Ramakrishnan, U., Ndiaye, A., Haddad, H., and Martorell, R. 2003. The importance of women's status for child nutrition in developing countries. IFPRI Research Report 131. International Food Policy Research Institute, Washington, DC.

Sun, Y., Mwangi, E. and Meinzen-Dick, R. 2011. Is gender an important factor influencing user groups' property rights and forestry governance? Empirical analysis from East Africa and Latin America. International Forestry Review 13(2): 205-19.

Sunderland, T., Achdiawan, R., Angelsen, A., Babigumira, R., Ickowitz, A., Paumgarten, F., Reyes-García, V. and Shively, G. Under review. Myths and realities about men, women and forest use: A global comparative study.

World Bank, FAO and IFAD. 2009. Gender in agriculture sourcebook. The International Bank for Reconstruction and Development, The World Bank, Washington, DC. 


\section{Annex I \\ Gender-specific research questions across the five components}

\author{
Broad research questions \\ (Component 1, Theme 1) \\ How does one increase \\ investment in species-specific \\ tree improvement using generic \\ domestication techniques for \\ priority NTFP and tree species to \\ ensure quality planting material \\ is available? \\ What approaches, tools and \\ methods can be used to adapt \\ tree and forest management \\ techniques to the scales, \\ resource types, objectives and \\ opportunities of smallholders \\ and community forest \\ managers?
}

How and why do different tree species $\mathrm{x}$ management options confer affordable sustainability benefits for farmers in terms of higher soil and water productivity in the medium to long term?

\section{How can innovative} management techniques be used to improve NTFP and tree use to diversify farming systems and enhance rural livelihoods?

How can innovative management techniques (locally derived and science based) be identified, tested and evaluated more efficiently?

Which farmer, forest and tree management skills can be enhanced with respect to establishment, protection, spacing, thinning, selection, pruning, coppicing, harvesting, irrigation and fertilisation?

\author{
Gender-specific aspects of the \\ question \\ What interventions (e.g., policies) \\ can improve women's access to \\ important NTFP and tree species for \\ germplasm collection and use?
}

How does one ensure that promotion and domestication of high-value NTFP and tree species are based on men's and women's differentiated preferences (products and species)?

How do gender-differentiated roles and control of resources affect species and management preferences and ultimate choices? What changes in women's control of tree and land resources are necessary for their preferences to prevail in decisions about tree planting, retention and management?

How does the introduction of innovation or intensification affect gender roles or differential access to resources and benefits?

How do knowledge and preferences of women and men differ in relation to choices of tree species and management options?

How does one consider gender roles and targeted training in different forest/tree management activities to promote complementarity of skills, especially in labour-scarce households?
Examples of science outputs

New/improved tree and crop germplasm

NTFP and tree domestication strategies

Best practice guidelines

Forest and tree management tools

Development of associative tree ideotypes and hence system-compatible tree germplasm

Tools for matching trees and tree mixtures to sites and circumstances

Tools for promoting tree diversity on farms and in farming landscapes

Databases of scientific and local assessments of tree attributes that confer productivity gains and system compatibility

Forest and tree management manuals

Databases

Demonstration sites 
Annex I. Continued

\begin{tabular}{l} 
Broad research questions \\
(Component 1, Theme 2) \\
\hline What improved methods and \\
rapid appraisal tools can be \\
used to analyse the actual and \\
potential value of forest and tree \\
products for poor and women \\
farmers and for subsector and \\
value chains (including inputs, \\
nurseries)?
\end{tabular}

What scaling-up and novel extension approaches are effective in promoting the spread of knowledge and materials (e.g., seed), particularly among women and the poor, are sustainable and help build capacities of communities to access information and innovate? How does the impact of innovative extension approaches vary by commodity, by land use system, by social setting and by region?

What are key marketing interventions for helping farmers improve returns from NTFP and agroforestry enterprises and improve smallholder competitiveness? How should the interventions be sequenced?

What are the multiplication and deployment systems for improved tree germplasm that ensure genetic integrity, provide disease-free planting material, and are adapted to various local conditions?

What innovative and sustainable ways can be devised and implemented to improve the supply of market information, technical assistance and appropriate finance to differentiated, local end-users of forest- and tree-based production systems?

How can certification of good agricultural practices and sustainable timber practices incentivise farmers to modify their tree-planting decisions?

\section{Gender-specific aspects of the question}

How does one increase women's participation in value chains and reduce inequity in household benefits?

Appraisal tools should be gender sensitive and inclusive.

How does one ensure that scalingup and extension approaches and interventions are specifically targeted to cultural and gender differences, according to men's and women's different participation in commodities, land use systems and social settings?

Collective marketing enables smallholders to 'break into' the market, but gender relations can break down the collective if not attended to.

Are the methods of multiplication accessible for both men and women?

Community-based market information platforms are innovative and can be effective in supplying timely market information and getting feedback, but conflicts of interest and power relations between men and women in mixed platforms need investments in repairs and maintenance.

How does one improve women's participation in value chains and reduce inequity in household benefits?

Appraisal tools should be gender sensitive and inclusive.

\section{Examples of science outputs}

Rapid appraisal tools of market chains

Viability and profitability studies

Value chain reports

Fair pricing guidelines

\section{Novel extension approaches}

Scaling-up protocols

Rural resource centres

\author{
Marketing strategies \\ Franchising options \\ Outgrower schemes
}

Cultivar multiplication and deployment systems for tree crops identified and evaluated

Locally adaptable tree seed and seedling systems and means of selecting appropriate models for different settings, developed and tested for both high-value and highvolume species
Market information systems
Information hubs
Microcredit schemes
Decentralised extension approaches
Demonstrations

Certification checklists

Generic criteria

Publications 
Annex I. Continued

\begin{tabular}{|c|c|c|}
\hline $\begin{array}{l}\text { Broad research questions } \\
\text { (Component 1, Theme 3) }\end{array}$ & $\begin{array}{l}\text { Gender-specific aspects of the } \\
\text { question }\end{array}$ & Science outputs \\
\hline \multirow{3}{*}{$\begin{array}{l}\text { How can multilevel governance } \\
\text { institutions best work to } \\
\text { enhance local rights and } \\
\text { livelihoods? }\end{array}$} & \multirow{3}{*}{$\begin{array}{l}\text { How can women participate } \\
\text { effectively in multilevel governance } \\
\text { institutions and what is needed to } \\
\text { overcome barriers to participation? }\end{array}$} & $\begin{array}{l}\text { Tools for facilitating collaboration necessary } \\
\text { for multilevel governance }\end{array}$ \\
\hline & & $\begin{array}{l}\text { Approaches for analysing multilevel and } \\
\text { polycentric governance systems }\end{array}$ \\
\hline & & $\begin{array}{l}\text { Tools for overcoming barriers to women's } \\
\text { participation }\end{array}$ \\
\hline \multirow[t]{3}{*}{$\begin{array}{l}\text { What mechanisms can improve } \\
\text { smallholder and community } \\
\text { access and control over forest } \\
\text { and tree resources? }\end{array}$} & $\begin{array}{l}\text { How does one build bargaining } \\
\text { power and confidence among } \\
\text { women in seeking equitable access } \\
\text { and control over forest and tree } \\
\text { resources in mixed environments? }\end{array}$ & \multirow[t]{2}{*}{$\begin{array}{l}\text { Generic tools for analysing access in the } \\
\text { context of legal pluralism; synthesis of local } \\
\text { experience and emerging patterns; and } \\
\text { analysis of factors that foster or constrain } \\
\text { multilevel collective action for securing local } \\
\text { rights and access }\end{array}$} \\
\hline & \multirow{2}{*}{$\begin{array}{l}\text { How does one link local women's } \\
\text { organisations to national and } \\
\text { international movements to }\end{array}$} & \\
\hline & & $\begin{array}{l}\text { Operational guidelines for assessing tenure } \\
\text { constraints and opportunities }\end{array}$ \\
\hline
\end{tabular}

How does one better integrate scientific and local knowledge to improve management institutions that govern forest and tree resources?

What policies can protect livelihoods and enhance wellbeing given greater pressures (e.g., market integration, REDD+, biofuel expansion)?

How can forest policies
better respond to needs
for tree management in
agricultural lands and what
institutional reforms can lower
barriers between forestry
and agriculture to serve the
different tree germplasm and
information needs for forestry
and agroforestry development?
How can technical norms
and regulations be tailored
to reflect the contexts,
constraints and opportunities
faced by smallholders and
community-level producers?
better respond to needs for tree management in agricultural lands and what institutional reforms can lower barriers between forestry and agriculture to serve the different tree germplasm and information needs for forestry and agroforestry development?
How does one ensure gender differences in knowledge and learning styles are understood in the cultural context? increase their voice and strengthen

their rights and access to forest resources and to market opportunities in forest and tree products?

How can property rights and security for women best be enhanced, particularly with regard to common or communal property?

How does one recognise and address different states/levels/types of knowledge between genders regarding forest and tree resources? What approaches ensure that women's knowledge and preferences are heard when attempting to modify resource governance systems?

How does one ensure the inclusion of pro-women policies to adjust negative results caused by gender power relationships?

How do reforms of forest policies in response to needs in agroforestry affect female farmers or tree managers?

\section{Analytical tools \\ Synthesis of site-level experience}

Smarter policy formulations that do not have perverse outcomes on tree resources on agricultural land

Analysis and synthesis of ways to link knowledge with action 
Annex I. Continued

Broad research questions
(Component 1, Theme 3)

In what ways can local level institutions for collective use and management of forest resources (including rights and access) be recognised and taken into account by higher-level rules, strategies and procedures without compromising their functions and effectiveness?

\section{What innovations in} incentives, including rewards, sanctions, responsibilities and discretion can improve the implementation of policies and laws by officials (especially frontline bureaucrats)?

\section{Broad research questions (Component 2, Theme 1)}

What are the most important criteria for identifying priority tree species and populations for conservation action at subnational, national and regional levels?

What are the status, trends, threats and major drivers of loss of intra- and interspecific forest and tree biodiversity that are of socioeconomic importance? Considering that most countries have policies for biodiversity conservation, what impedes implementation?

What are the most effective and practical indicators of genetic diversity (including ecological proxies) across landscapes (including seminatural, managed and planted forests)?

What is the best combination of in situ, ex situ and/or circa situ (on-farm) conservation approaches and how can challenges to their implementation be overcome for priority tree species (including fruit trees and tree crops across the forest-to-farm spectrum)?

\section{Gender-specific aspects of the question}

What elements of gender-

differentiated rules, norms and practices for collective use and management can be reasonably formalised without undermining men's and women's capacities for collective organisation? What are the sustainability and benefit distribution effects of different structural and functional attributes of groups?

In what ways are forestry officials' implementation practices (e.g., enforcement) gender differentiated? How do they affect men's and women's compliance and incentives for sustainable forest management?

$\begin{array}{ll}\begin{array}{l}\text { Gender-specific aspects of the } \\ \text { research question }\end{array} & \text { Examples of science outputs } \\ \begin{array}{l}\text { How could the different priorities } \\ \text { of men and women be considered } \\ \text { more equally when defining }\end{array} & \begin{array}{l}\text { Criteria for prioritising useful diversity from } \\ \text { local to country levels developed and tested } \\ \text { together with local and national partners }\end{array}\end{array}$
common priorities? How can understanding the different gender roles help refine priorities?

Do men and women value species and traits differently and play different roles in and/or experience different effects from the drivers of diversity loss? Who loses, relatively and quantitatively, when different types of diversity are lost?

How can one encourage equitable participation in strategy development and outcomes? How do conservation strategies affect men and women and their access to resources? What kinds of checks should be included in tools to address gender impacts?

Women are important processers and quality controllers of many fruits. How can their role be recognised?
Organisational strategies and interventions for improving officials' incentives
Methods and approaches for incorporating and/or recognising local-level institutions (including rights and access) that are sensitive to gender-differentiated needs and priorities
Genetic diversity, useful traits, conservation status and threats assessed for priority species groups

Methods for threat analysis and understanding of in situ conservation status, along with identification of viable solutions

Practical, applicable, interpretable indicators of genetic resources for use across the landscape gradient

Methodology for rapid in situ evaluation of diversity of useful traits of wild and semidomesticated fruit tree species

Methods, guidelines and decision support tools developed and disseminated for complementary in situ, ex situ and circa situ conservation strategies for priority tree species and populations that facilitate their use in improvement and development activities

Systems and procedures established for effectively conserving genetic diversity of tree crops 
Annex I. Continued

\begin{tabular}{l} 
Broad research questions \\
(Component 2, Theme 1) \\
\hline Which elements must be \\
included in guidelines or \\
strategies for conservation of \\
genetic resources for uptake and \\
adoption in high-poverty areas \\
and by different user groups, \\
including women and men? \\
\hline Broad research questions \\
(Component 2, Theme 2) \\
\hline How can key genetic traits in \\
wild and local populations be \\
quickly identified such that \\
high-quality germplasm of \\
socioeconomically important \\
tree species can be conserved? \\
What are the most cost-effective \\
ways of conserving desired traits \\
in wild and local populations?
\end{tabular}

How can users (e.g., researchers, breeders, farmers) get rapid access to desired genetic resources and local germplasm?

What institutional frameworks are effective and cost efficient in ensuring genetic resources conservation, and in providing access to and use of trees and tree crops?

\section{Gender-specific aspects of the research question}

How can equitable participation and influence in the strategy development processes, by different user groups, be encouraged?

\section{Examples of science outputs}

Genetic diversity conservation strategies developed for socio-economically important tree species, for high-poverty areas

Methodologies and incentive mechanisms identified for in situ and on-farm conservation of tree crop genetic resources

\section{Gender-specific aspects of the} research question

What traits are important for men and women, taking into account their different roles and resources?

What knowledge do they each have and how do they identify valuable traits?

What roles can women and men play in conserving valuable local and wild populations that they have access to and use?

Are the primary users of genetic resources seeking priority traits identified by women and men for their different roles and resources?

How do we ensure that genderspecific aspects are built into a sustainable institutional framework?
Examples of science outputs

Assessment of feasibility of using genomic tools to find sources of variation in important adaptive and useful traits

Methodologies/standards for phenotypic and genetic characterisation of genetic resources developed and agreed

System and procedures established for effectively conserving important genetic diversity

Information systems and databases on genetic resources established or strengthened

Systems and procedures established for making important genetic diversity of tree crops available to breeders

Global partnership frameworks for the evaluation and conservation of and access to tree crop germplasm for important traits established

\section{Broad research questions (Component 2, Theme 3)}

What forest management policies and practices can provide sustainable incomes and incentives for maintaining environmental services, while protecting the natural resource base, and under what conditions?

How can we go 'beyond timber'? What management interventions are needed to maximise the total array of benefits (environmental, social, economic) from forests?

\section{Gender-specific aspects of the research question}

What factors affect distribution of incomes from different approaches? How are non-monetary benefits (e.g., domestic use) affected? Who do incentives target and what factors influence targeting? What are the constraints on women benefiting?

How can men and women share responsibility as resource managers, users and knowledge holders? How can forest managers be sensitised and how can their capacities to identify and consider gendered roles, preferences and knowledge be enhanced? What processes and accountabilities are required to ensure that the analysis of forest products takes into account postharvest processing possibilities and constraints by men and women for different products?

\section{Examples of science outputs}

Development of tools, methods and guidelines for better monitoring and management of tropical production forests for multiple uses and beneficiaries

New silvicultural tools, harvesting guidelines and approaches that avoid local extinction of commercial timber species and attempt to integrate biodiversity considerations (including bushmeat) and other environmental or cultural services into management plans 
Annex I. Continued

\section{Broad research questions (Component 2, Theme 3)}

Does forest certification contribute to the achievement of SFM in tropical production forests or is it simply adding cost and complexity without providing sufficient corresponding commercial advantage?
What is the minimum set of criteria to include for allocating efforts to rehabilitate degraded ecosystems for the provision of multiple goods and services at the stand and landscape levels?

How can agreements be facilitated in existing large and complex stakeholder networks around tropical production forests?

\section{Gender-specific aspects of the research question}

Who participates and what are the conditions for participation in the development of standards? What alternative processes and strategies can be adopted to broaden participation? Who benefits in terms of resource conservation and increased incomes and why? How can market-based mechanisms on a global level address and ensure distributional equity and outcomes at the site of production? What innovative solutions and institutions (responsibilities and accountabilities) can be crafted at different governance levels (local, national, global) to facilitate equitable outcomes?

Differential gender appropriation of the provision of forest goods and services from rehabilitated forests and gender-specific traditional knowledge as an input of silvicultural practice

Analysis and recognition of power relations (including influencing factors) in order to design procedures and strategies for increasing the bargaining power of marginalised actors. What resources are irreplaceable for each gender and should thus be addressed as a priority?

\section{Broad research questions (Component 2, Theme 4)}

What do local people (men, women, old, young, dominant and marginalised ethnic groups) value about the production forests in which (or near which) they live?

What strategies exist and can be developed for bringing together the ideas of formal production forest managers and local community members (including women and other marginalised groups)?

How can agreements be facilitated in existing large and complex stakeholder networks around tropical production forests?

\section{Gender-specific aspects of the research question}

How do differential roles in the community explain and affect valuations among multiple interests and to what extent are people able to express their views and influence decisions on forest management?

How have existing strategies performed and how can they be structured and improved to better meet objectives? How do groups' and individuals' power relationships help to explain their attitudes and their actions? How would recognition of sensitisation and capacity-building needs help to achieve common understanding?

Analysis and recognition of power relations. What resources are irreplaceable for each gender and should thus be addressed as a priority?

\section{Examples of science outputs}

Identification of stand-level trade-offs in multiple-use management systems as they relate to regulatory frameworks, certification and knowledge capacity and silvicultural approaches

Decision support systems and best practice guidelines, including genetic, ecological and silvicultural approaches

Guidelines and mechanisms developed for use of government agencies, certification bodies, private enterprises and communities

\section{Examples of science outputs}

Guidelines/uses developed for forest resources that incorporate and recognise local values

Guidelines and mechanisms for forest resource use developed that reconcile/ resolve trade-offs and build common understanding between forest managers and communities

Guidelines and mechanisms developed for use of government agencies, certification bodies, private enterprises and communities 
Annex I. Continued

\begin{tabular}{l} 
Broad research questions \\
(Component 3, Theme 1) \\
\hline What are the major drivers \\
and patterns of qualitative \\
and quantitative tree cover \\
transitions and how do they vary \\
with scale in space and time? \\
What are the consequences of \\
commercial logging and forest \\
conversion for migrant-based \\
agriculture or plantations? \\
What is the impact of \\
infrastructure development and \\
how can negative consequences \\
on the environment and \\
livelihoods be mitigated? \\
How do local stakeholders \\
interact with external ones \\
in various stages of forest \\
transition? \\
How do governance systems \\
and their reform influence \\
stages in forest transition at the \\
forest/agrarian interface?
\end{tabular}

Gender-specific aspects of the
research question

How are the perceptions, appreciation and experiences of tree cover transitions influenced by gender? What are the gender impacts of such transitions? How do different factors that influence transition, including governance arrangements, incentives and institutional reform, interact with gender dynamics to produce better outcomes?

\section{Examples of science outputs}

Empirical (including time series) data sets of quantitative and qualitative tree cover transitions across continents

Analysis of the links between the drivers of land use and tree cover change at global/ national/local scales, including their relationships with:

- demographic change, including changes in rates of urbanisation, circular and other migration patterns, and human population density

- road networks, and other infrastructure (e.g., pipelines, hydrocarbon fields, dams, mines)

- the processing industry (linked to Component 5)

- national supply/demand and import/ export data and overall economic development

- forest categorisation and forest policy regimes

Identification of opportunities to negotiate and influence the reversal of current degradation patterns and acceleration of forest rehabilitation and agroforestry transformation

\section{Examples of science outputs}

Gender-specific as
research question

How does preference for 'quantifiable' environmental services (ES) vary between genders, based on the perceived direct value of ES and foreseeable benefits, influencing the level of participation?
Tools for determining and quantifying the environmental services at stake in various stages of tree cover transition

Strategies and practices for managing tree species to conserve genetic resources today and for the future at the scale of landscapes

Strategies and practices for sustaining ecological functionality in multiple-use landscape mosaics biogeographic, ecological and socioeconomic contexts? What are the most effective methods for assessing environmental service provision and changes that result as a function of landscape-level disturbance?

What holistic combination of in situ (including managed forests), ex situ and circa situ (on-farm) conservation approaches are most effective for conserving key populations of priority species and their genetic diversity at the scale of landscapes? 
Annex I. Continued

\begin{tabular}{|c|c|c|}
\hline $\begin{array}{l}\text { Broad research questions } \\
\text { (Component 3, Theme 2) }\end{array}$ & $\begin{array}{l}\text { ender-specific aspects of the } \\
\text { esearch question }\end{array}$ & Examples of science outputs \\
\hline $\begin{array}{l}\text { be combined in ways that } \\
\text { reduce environmental } \\
\text { service deficits? }\end{array}$ & \multirow{2}{*}{$\begin{array}{l}\text { How do gender roles influence } \\
\text { participation in negotiation of } \\
\text { PES schemes? What approaches, } \\
\text { including timing, sequencing and } \\
\text { overall design of PES negotiation } \\
\text { processes, are necessary for } \\
\text { ensuring effective participation? }\end{array}$} & $\begin{array}{l}\text { local stakeholders are supported and } \\
\text { enabled to enhance environmental service } \\
\text { provision as well as their livelihoods }\end{array}$ \\
\hline $\begin{array}{l}\text { How do outcomes of } \\
\text { negotiations over conservation } \\
\text { and development trade-offs } \\
\text { vary in relation to such factors }\end{array}$ & & $\begin{array}{l}\text { Tested tools and governance mechanisms } \\
\text { for managing the trade-offs between } \\
\text { conservation and development at } \\
\text { multiple scales }\end{array}$ \\
\hline
\end{tabular}
as stakeholders' negotiation capacity, scientific input and inclusiveness of participation and gender considerations? the various cultural contexts, gender roles and representation in policy dialogues in light of integration?

How realistic are expectations that regulation of and incentives for enhancing tree-based watersheds, carbon storage and biodiversity services can enhance and sustain environmental services?

What are the trade-offs between efficiency, perceived fairness and measurable equity, and poverty reduction associated with alternative mechanisms for environmental service rewards for smallholder farmers, both men and women?

How can cross-sectoral policies and community-based forest policy limit or enhance the potential for environmental service rewards?

How can policies, tools, methods and approaches enhance the sustainability of financial flows, and improve governance and institutions?

Under what conditions and at what scales can PES schemes and related mechanisms produce positive outcomes for conservation and human wellbeing that are effective, efficient and equitable?

How can forestry and agroforestry initiatives best interact with the drivers of forest and landscape transitions?

How can forestry and agroforestry and the perspectives of women (and other marginalised actors) be included in policies? What strategies, and at what stages in the sequence of policy design, will ensure effective participation of women and other marginalised actors?
Overview of current policies for the agriculture-forestry interface that can be adjusted to maximise positive environmental and socioeconomic outcomes 
Annex I. Continued

\begin{tabular}{|c|c|c|}
\hline $\begin{array}{l}\text { Broad research questions } \\
\text { (Component 3, Theme 3) }\end{array}$ & $\begin{array}{l}\text { Gender-specific aspects of the } \\
\text { research question }\end{array}$ & Examples of science outputs \\
\hline \multirow{3}{*}{$\begin{array}{l}\text { How can multi-stakeholder, } \\
\text { multifunctional landscapes } \\
\text { evolve from a conflict- } \\
\text { dominated state to one that } \\
\text { involves negotiation and use of } \\
\text { opportunities for synergy-with } \\
\text { positive environmental and } \\
\text { social outcomes? }\end{array}$} & $\begin{array}{l}\text { Do conserved and other forests } \\
\text { have different values and } \\
\text { accessibility for men and women? }\end{array}$ & \multirow{4}{*}{$\begin{array}{l}\text { Identification of principles, methods and } \\
\text { processes for optimising conservation and } \\
\text { livelihood values from the allocation of land } \\
\text { use rights within forest landscapes } \\
\text { Collaborative decision-making and } \\
\text { monitoring tools for strengthening } \\
\text { community involvement and meaningful } \\
\text { participation in conservation and land use } \\
\text { planning, especially by women and other } \\
\text { disadvantaged stakeholders }\end{array}$} \\
\hline & \multirow{3}{*}{$\begin{array}{l}\text { What kind of conflicts may occur } \\
\text { within communities and how might } \\
\text { their nature and intensity vary } \\
\text { by gender? } \\
\text { What options exist for conflict } \\
\text { management and resolution that } \\
\text { draw upon the relative strengths of } \\
\text { men and women? }\end{array}$} & \\
\hline & & \\
\hline \multirow{4}{*}{$\begin{array}{l}\text { How do the outcomes } \\
\text { of negotiations between } \\
\text { conservation and development } \\
\text { trade-offs systematically vary } \\
\text { in relation to such factors as } \\
\text { negotiation capacity of various } \\
\text { stakeholders, scientific input and } \\
\text { inclusiveness of participation? }\end{array}$} & & \\
\hline & $\begin{array}{l}\text { How can different abilities to } \\
\text { participate and negotiate, including } \\
\text { bargaining power, between men } \\
\text { and women be accounted for and } \\
\text { addressed? }\end{array}$ & \\
\hline & $\begin{array}{l}\text { How does one facilitate equitable } \\
\text { land use rights allocation and } \\
\text { women's ability to maintain rights? }\end{array}$ & \\
\hline & $\begin{array}{l}\text { What kinds of safeguards are } \\
\text { required in rights allocation } \\
\text { processes to ensure equitable and } \\
\text { effective rights and access? }\end{array}$ & \\
\hline \multirow{6}{*}{$\begin{array}{l}\text { How can conservation } \\
\text { and livelihood objectives } \\
\text { be reconciled at the } \\
\text { landscape scale? }\end{array}$} & \multirow{2}{*}{$\begin{array}{l}\text { How do species uses differ between } \\
\text { user groups and how should } \\
\text { these be taken into account in } \\
\text { conservation and management? }\end{array}$} & $\begin{array}{l}\text { Identification of improved modalities } \\
\text { and approaches to effectively support } \\
\text { conservation in forest landscape mosaics }\end{array}$ \\
\hline & & \multirow{5}{*}{$\begin{array}{l}\text { Participatory models for reserve managers } \\
\text { to identify how reserve dwellers use } \\
\text { particular resources and threaten long-term } \\
\text { sustainability of targeted species; monitor } \\
\text { current uses; and develop guidelines for } \\
\text { conservation and sustainable management } \\
\text { of species and populations of value }\end{array}$} \\
\hline & $\begin{array}{l}\text { How does one resolve conflicting } \\
\text { uses between multiple users within } \\
\text { and among communities? }\end{array}$ & \\
\hline & $\begin{array}{l}\text { How does one empower women by } \\
\text { recognising and strengthening their } \\
\text { role in and livelihood benefits from } \\
\text { resource management? }\end{array}$ & \\
\hline & $\begin{array}{l}\text { What might be the unintended } \\
\text { consequences of such } \\
\text { empowerment and how can such } \\
\text { consequences be mitigated and/ } \\
\text { or avoided? }\end{array}$ & \\
\hline & $\begin{array}{l}\text { What suite of incentives, knowledge } \\
\text { and resources is required to } \\
\text { enhance reserve managers' } \\
\text { gender sensitivity? }\end{array}$ & \\
\hline
\end{tabular}


Annex I. Continued

\begin{tabular}{ll}
\hline $\begin{array}{l}\text { Broad research questions } \\
\text { (Component 4, Theme 1) }\end{array}$ & $\begin{array}{l}\text { Gender-specific aspects of the } \\
\text { research question }\end{array}$ \\
\hline Focus 1 (Policies) & Do mitigation modalities have \\
What design elements of & $\begin{array}{l}\text { gender-specific aspects that have } \\
\text { to be taken into account? What }\end{array}$ \\
international agreements, & factors condition the use and \\
finance and capacity- & implementation of gender-specific \\
building efforts are & elements of mitigation modalities? \\
necessary to produce & How could international REDD+ \\
efficient, effective and & agreements affect women and \\
equitable REDD+ policies & disadvantaged groups? \\
and initiatives? &
\end{tabular}

Focus 1 (Policies)

How do national policies and institutions influence the formulation and implementation of efficient, effective and equitable REDD+ policies?

Focus 2 (Subnational)

How does the local context determine the design of a REDD+ initiative?

How can the interests of women and disadvantaged groups be addressed in national REDD+ strategies? What kinds of measures and obligations can be incorporated into national policy and planning processes to increase the likelihood that the interests, knowledge and needs of disadvantaged groups (including women) are effectively articulated?

\section{Examples of science outputs}

Global analysis of agreements and options for a global climate regime and their likely outcomes for REDD+, including analysis of convergence and divergence of opinions

Analysis of comparative advantages/ disadvantages of the various financing arrangements to shape the political economy in recipient countries

Recommendations on international agreements, based on a comparative analysis of their effects on the formulation and implementation of efficient, effective and equitable REDD+ policy and initiatives

Analysis of the political economy of REDD+ at the national scale, including the role of non-state actors in shaping the national debate on REDD+ and the value judgments about the achievable efficiency, effectiveness and equitability of REDD+ Assessment of the effects of REDD+ policies on national economies and national or international markets, especially timber and fuelwood (linked with Component 5)

Recommendations on institutional frameworks at the national level within which REDD+ can be effectively implemented and ensure service delivery, deal making, identification of tradeoffs and mediation in the current context of proliferating pilot projects and a fragmented policy arena

Guidelines to improve the transparency, inclusiveness and efficiency of REDD+ policymaking processes and associated reforms (e.g., tenure reform and intersectoral planning), based on comparative analysis

Comparative analysis of how de jure and de facto tenure rules and forest tenure reform affect the security of local populations and REDD+ initiatives Analysis of the political economy of REDD+ initiatives (how different local actors exercise authority in interaction with national actors, how multilevel forest governance processes influence land use)

Recommendations on institutional designs or mechanisms promoting inclusive decision making, accountability and legitimacy in subnational initiatives, particularly with regard to community and market actors

Recommendations on the design of REDD+ initiatives (e.g., in terms of payments and benefit sharing, involvement of local institutions), depending on the type of forests and forest management (e.g., conservation vs production forests), institutions (e.g., tenure, decentralisation, community institutions) and social context 
Annex I. Continued

\begin{tabular}{l} 
Broad research questions \\
(Component 4, Theme 1) \\
\hline Focus 2 (Subnational) \\
How can a REDD+ \\
initiative contribute to \\
livelihood improvement, \\
equitable benefit \\
sharing (including \\
across genders), tenure \\
clarification and leakage \\
prevention?
\end{tabular}

Focus 3 (Methods and tools)

What are the best practices and decision to carbon and baseline estimation? support tools related

\author{
Gender-specific aspects of the \\ research question

\section{Examples of science outputs}

What are the differentiated impacts of REDD+ initiatives on women's rights and livelihoods? How do gender relationships explain these differentiated impacts? How might gendered relationships intensify these impacts?

None

What are the best methods for understanding the differentiated roles of women and disadvantaged groups in tree- and forest-based mitigation initiatives? What kinds of practices can foster inclusiveness while minimising distributional conflict among beneficiaries including women and other disadvantaged groups?

\section{Gender-specific aspects of the research question \\ Examples of science outputs}

(Component 4, Theme 2)

\section{Focus 1 (Policies)}

How can international and national policies and funds improve the design and implementation of adaptation initiatives that reduce the vulnerability of people and ecosystems?
How can national adaptation strategies and policies integrate the interests of women and disadvantaged groups? How should negotiation and planning processes be structured, sequenced and timed to allow for the effective representation and/or participation of disadvantaged groups?
Comparative analysis of how REDD+ initiatives affect local governance arrangements and livelihoods, including women and disadvantaged groups and their access to forest products, markets and diversified economic activities Analysis of how REDD+ initiatives affect noncarbon ecosystem services (e.g., hydrological services affected by reforestation) and local economies (e.g., small-scale traders, merchants, artisans)

Guidelines for designing pro-poor REDD+ initiatives (e.g., in terms of benefit sharing, tenure clarification and leakage prevention)

Best practice and decision support tools for measuring and estimating carbon balance in mitigation initiatives and baseline scenarios (carbon stocks and greenhouse gas emissions in biomass, soils, forest products and forest or agricultural activities)

Best practice and decision support tools for managing trees and forests in REDD+ projects (e.g., selection of adequate species for tree planting depending on ecological and socioeconomic context)

Improved and validated approaches for participatory design and planning of tree- and forest-based mitigation initiatives, including negotiation tools for addressing trade-offs and defining achievable targets in terms of efficiency, effectiveness and equitability

Approaches to participative monitoring and management of carbon stocks

Analysis of the effects of international decisions on adaptation and funding modalities and their effectiveness, equity and efficiency

Comparative analysis of the effects of national policies and processes (e.g., decentralisation, tenure reform, agriculture policy, trade and investment) on people's adaptive capacity Guidelines to improve national policies for strengthening local adaptive capacity under different contexts

Guidelines on how to incorporate adaptation into forest policies and forests and trees into adaptation policies 
Annex I. Continued

Broad research questions
(Component 4, Theme 2) $\begin{aligned} & \text { Gender-specific aspects of the } \\ & \text { research question }\end{aligned}$

Focus 2 (Subnational) None

How will climate change affect forests and trees?

What measures can be designed for reducing ecosystem vulnerability?

\section{Examples of science outputs}

Regional assessments of climate change impacts on forests and trees (e.g., fires, storm, pests, dieback, suitable tree crops)

Assessment of the resilience of forest and tree ecosystems (including tree crop systems under different management) to climate change Guidelines for identifying and implementing adaptation options for forests and trees, including landscape-scale measures (e.g., biological corridors), forest management measures (e.g., improved planting or harvesting) and tree diversity management (e.g., appropriate tree planting materials and germplasm delivered to farmers)

Focus 2 (Subnational) How resilient are forestand tree-dependent people in the face of climate change and an array of other drivers of profound change?

What institutional and technical measures (e.g., institutional reforms, technical measures and ecosystem management) can be designed for reducing the vulnerability of forest- and treedependent people and economic sectors?
Focus 3 (Methods and tools)

What are cost-effective methods and tools for assessing the impacts of climate change on forests, agroforestry and biodiversity (including genetic resources) and for determining adaptation options for ecosystems?
What are the gender-differentiated vulnerabilities of local people to climate change? How do local social and political institutions (e.g., property rights, patronage) shape gendered vulnerabilities?

Do men and women perceive adaptation needs and strategies differently? What is the differentiated role of women in local adaptive strategies?

How do gender inequalities explain differentiated vulnerabilities? How can the adaptive capacity of women and disadvantaged groups be enhanced?

None

Analysis of the vulnerability of local communities to climate variability and climate change, in interaction with other socioeconomic and political changes

Documentation and comparative assessment of past and current local adaptive strategies and coping responses of local communities

Comparative analysis of how local and national institutions affect the adaptive capacity of local communities

Analysis of the role of ecosystems in reducing the vulnerability of local communities and society to climate change (e.g., through water regulation, diversification of livelihoods ensured by tree crops, products for energy and health, regulation of microclimate)

Analysis of the trade-offs between different adaptation options (ecosystem-based measures and other measures) and between different land uses

Recommendations on how to design societal adaptation with ecosystem-based measures and other measures

Recommendations on governance reforms and local institution strengthening for adaptation

Methods and tools for assessing the potential impacts of climate change on forests, agroforests and their genetic diversity, taking into account non-climatic drivers of change

Modelling approaches for assessing the impacts of climate change on ecosystem services

Methods for assessing the effectiveness of adaptation measures for ecosystems (e.g., biological corridors, enhancement of genetic diversity for resilience)

Methods for understanding adaptive genetic variation in tree species (e.g., climate change genomic studies) and guiding germplasm exchanges of suitably adapted or plastic material 
Annex I. Continued

\begin{tabular}{lll}
\hline $\begin{array}{l}\text { Broad research questions } \\
\text { (Component 4, Theme 2) }\end{array}$ & $\begin{array}{l}\text { Gender-specific aspects of the } \\
\text { research question }\end{array}$ & Examples of science outputs \\
\hline $\begin{array}{l}\text { Focus } 3 \text { (Methods } \\
\text { and tools) }\end{array}$ & $\begin{array}{l}\text { How does one study the role } \\
\text { of ecosystem services in the } \\
\text { livelihoods and the adaptation of }\end{array}$ & $\begin{array}{l}\text { Best practices (combining biophysical-economic } \\
\text { modelling and participatory assessment) for } \\
\text { analysing the role of local ecosystem services }\end{array}$ \\
$\begin{array}{l}\text { practices and decision } \\
\text { support tools for }\end{array}$ & women and disadvantaged groups? & $\begin{array}{l}\text { in the adaptation of local people and the } \\
\text { broader society }\end{array}$
\end{tabular}

managing ecosystem

services in ecosystem-

based adaptation?

Focus 3 (Methods and tools)

What are the most appropriate methods for involving forestdependent communities in adaptation initiatives?

\section{Broad research questions (Component 4, Theme 3)}

\section{Focus 1 (Policies)}

What are the opportunities and modalities for linking $M \& A$ in international and national policies?

Focus 1 (Policies)

What governance mechanisms are most effective in fostering the synergies between $M \& A$ ?

Focus 2 (Subnational) How does one increase the synergies between $M \& A$ in subnational and local initiatives?

Do smallholder resource use patterns exist that promote both $M \& A$ ?
How does one encourage the meaningful participation of women and disadvantaged groups in adaptation initiatives and planning processes?

What suite of tools and methods can best draw out genderdifferentiated knowledge and experiences?

\section{Gender-specific aspects of the research question}

How can linked M\&A policies increase attention to gender issues?

Improved and validated action research methods for assessing vulnerability and planning adaptation with local communities

Approaches to participatory monitoring of climate change impacts

\section{Examples of science outputs}

Comparative analysis of the trade-offs and synergies between M\&A in international and national policies and identification of opportunities for linking adaptation and mitigation

Assessment of the political economy of $M \& A$ trade-offs (e.g., mitigation as a global issue driven by developed countries vs adaptation driven by local and national needs in developing countries)

Recommendations for enhancing synergies between M\&A in international policies and funding

How can cross-sectoral and crossscale coordination for $M \& A$ include gender issues? What institutional arrangements, incentives and stakeholder interactions are required to ensure that $M \& A$ work synergistically to minimise gendered inequalities produced by climate change?

How can M\&A subnational initiatives include genderspecific aspects?
Analysis of how the performance of forestry- or climate-related institutions is affected by being embedded in larger architectures and addressing the objectives of both $M \& A$

Guidelines for governance reforms to foster crosssectoral planning for $M \& A$

Recommendations of institutional and financial mechanisms for fostering the synergies between M\&A (e.g., pro-poor payments for multiple ecosystem services)

Analysis of the impacts of climate change on the success of REDD+ initiatives (through impacts on forests and carbon, or impacts on local populations)

Recommendations on how to include adaptation in REDD+ initiatives for increasing social and ecological resilience

Guidelines for assessing the contribution of EBA initiatives to mitigation and facilitating their access to mitigation funding 
Annex I. Continued

$\begin{array}{ll}\begin{array}{l}\text { Broad research questions } \\ \text { (Component 4, Theme 3) }\end{array} & \begin{array}{l}\text { Gender-specific aspects of the } \\ \text { research question }\end{array}\end{array}$ Examples of science outputs

Focus 3 (Methods and tools)

What are the best practices and decision support tools for developing $M \& A$ initiatives?
What are the best methods for incorporating gender issues $n M \& A$ initiatives?

How does one address gender issues in the analysis of socioecological systems and the development of future scenarios?

Global synthesis on the trade-offs and synergies between M\&A in forest-, tree- and agroforestryrelated subnational and local initiatives

Guidelines to improve the design of $M \& A$ initiatives, in terms of institutions (e.g., funding and local governance) and techniques (e.g., resilient tree crop systems or multistrata silvopastoral systems, rehabilitation of ecosystems)

Analyses of which existing smallholder resource use patterns that promote $M \& A$ and how these may be built upon, scaled up, enhanced and included in M\&A initiatives

Methods and tools for mapping ecosystem services and analysing their trade-offs or synergies (carbon vs services relevant for adaptation)

Approaches for analysing the trade-offs and synergies between M\&A in terms of livelihoods and governance

Modelling approaches for studying the coupled dynamics of social and ecological systems and integrating knowledge from different disciplines and stakeholders

Best practices (e.g., combining scientific modelling and participatory assessment) for defining and analysing future scenarios and pathways for $M \& A$ Methods and tools for assessing ecosystembased M\&A measures, current and future costs and benefits

\section{Broad research question (Component 5, Theme 1)}

How do shifts in trade and investment associated with emerging economies (e.g., BRIC countries) and established markets differentially affect forests (e.g., area, ecological goods and services) and local people's livelihoods? What is the magnitude of these impacts and associated trade-offs?

How do demand for and investment in food, fuel and fibre change the type, location and degree of pressures on forest landscapes, thus shaping forest transitions? What are the impacts on forest and local people's livelihoods related to specific global-local interactions? What is the magnitude of these impacts and associated trade-offs?

\section{Gender-specific aspects of Examples of science outputs the research question}

Do impacts differ across gender groups? What factors explain differential impacts on men and women and their main variations? Do trade and investment intensify existing inequalities?

What conditions associated with trade and investment in different resources differentially affect men and women? What options and processes exist for gendersensitising codes of conduct for investors?
Assessment of processes, conditions and mediating factors through which trade and investment influence forest landscape changes and the livelihoods of forest-dependent people Analysis of the impacts associated with trade and investment trends on forests (including deforestation, forest degradation, biodiversity conservation, and provision of environmental services), people's livelihoods (men and women) and economic development

Methods and analysis of ecological, social and economic trade-offs associated with trade and investment at different scales of impact (local, subnational and national)

Comparative assessment of impacts on forests and people from global and domestic trade and investment trends across selected commodities and forest landscapes 
Annex I. Continued

\begin{tabular}{|c|c|c|}
\hline $\begin{array}{l}\text { Broad research question } \\
\text { (Component 5, Theme 1) }\end{array}$ & $\begin{array}{l}\text { Gender-specific aspects of } \\
\text { the research question }\end{array}$ & Examples of science outputs \\
\hline $\begin{array}{l}\text { How do land acquisition and } \\
\text { tenure regimes evolve under } \\
\text { the influence of growing } \\
\text { pressure on lands? What are } \\
\text { the impacts of land allocation } \\
\text { deals and tenure regimes (e.g., } \\
\text { concessions) that are linked to } \\
\text { the extraction of timber and } \\
\text { other forest resources and/or } \\
\text { the provision of environmental } \\
\text { services? How do they } \\
\text { influence and change resource } \\
\text { rights and the distribution } \\
\text { of benefits? }\end{array}$ & $\begin{array}{l}\text { What are the gender- } \\
\text { differentiated impacts } \\
\text { of business models or } \\
\text { conservation schemes } \\
\text { associated with large-scale } \\
\text { land investments? }\end{array}$ & \\
\hline $\begin{array}{l}\text { What interactions between } \\
\text { domestic and global timber } \\
\text { value chains are shaping forest } \\
\text { cover and forest livelihoods } \\
\text { in different forest landscapes? } \\
\text { What is the scale of illegal } \\
\text { logging associated with both } \\
\text { domestic and global timber } \\
\text { markets in specific landscapes, } \\
\text { and with what implications } \\
\text { for local livelihoods and forest } \\
\text { conditions? What are the } \\
\text { modes of operation used by } \\
\text { different stakeholders in the } \\
\text { domestic and global value } \\
\text { chains? What are their impacts } \\
\text { on forests (including goods and } \\
\text { services) and the distribution of } \\
\text { benefits in specific landscapes } \\
\text { and across gender groups? }\end{array}$ & $\begin{array}{l}\text { How are benefits of (formal } \\
\text { and informal) access and use } \\
\text { of forest resources linked to } \\
\text { global trade differentially } \\
\text { distributed between men and } \\
\text { women? What institutional } \\
\text { arrangements, including } \\
\text { policies, can serve to narrow } \\
\text { observed inequalities? }\end{array}$ & \\
\hline $\begin{array}{l}\text { What conditions and } \\
\text { loopholes in financial systems } \\
\text { and corporate governance } \\
\text { allow forest-related fraud } \\
\text { and corruption and socially } \\
\text { detrimental 'high-stakes' deals } \\
\text { to continue? What are the } \\
\text { interactions between illegal } \\
\text { logging and other forest } \\
\text { crime practices such as money } \\
\text { laundering? What is the scale } \\
\text { of and who are the actors in } \\
\text { financial fraud and corruption } \\
\text { associated with forest crime } \\
\text { and large-scale land and } \\
\text { resource transactions in select } \\
\text { countries and landscapes? }\end{array}$ & $\begin{array}{l}\text { Who benefits and who loses } \\
\text { from forest-related corruption, } \\
\text { fraud and money laundering } \\
\text { and large-scale land and } \\
\text { resource transactions? } \\
\text { How does the performance } \\
\text { of forest-related financial } \\
\text { governance systems affect } \\
\text { vulnerable groups, including } \\
\text { women? }\end{array}$ & \\
\hline
\end{tabular}


Annex I. Continued

\begin{tabular}{|c|c|c|}
\hline $\begin{array}{l}\text { Broad research questions } \\
\text { (Component 5, Theme 2) }\end{array}$ & $\begin{array}{l}\text { Gender-specific aspects of the } \\
\text { research question }\end{array}$ & Examples of science outputs \\
\hline $\begin{array}{l}\text { How do various models of non-state } \\
\text { market-driven governance systems } \\
\text { and corporate social responsibility } \\
\text { (e.g., timber certification, biodiversity } \\
\text { offsets, sustainability standards, } \\
\text { financial due diligence) differentially } \\
\text { reduce deforestation and forest } \\
\text { resource degradation, increase cover } \\
\text { of biodiverse forest and fulfil poverty- } \\
\text { reduction objectives? What are the }\end{array}$ & $\begin{array}{l}\text { How does one ensure that } \\
\text { market-driven models and } \\
\text { instruments 'do no harm' to } \\
\text { the most vulnerable groups, } \\
\text { and increase equity between } \\
\text { social groups in the pursuit of } \\
\text { improved social outcomes? }\end{array}$ & $\begin{array}{l}\text { Guidelines, based on comparative } \\
\text { analysis, of lessons learned on the } \\
\text { effectiveness of market-based } \\
\text { instruments and non-state processes, } \\
\text { for managing the impacts on forests and } \\
\text { people, increasing biodiverse and socially } \\
\text { beneficial forest and agroforestry cover, } \\
\text { and enhancing the social and economic } \\
\text { benefits from non-forestlands and forest } \\
\text { management }\end{array}$ \\
\hline
\end{tabular}
scope and scale of effectiveness of the different governance systems, and what institutional architectures are needed to support durable forest governance?

What policies, regulations and governance systems should be in place involving, on the one side, forest-rich producer countries (of timber, biofuel feedstocks, food and other commodities), and on the other, consumer countries:

- to reduce the pressures and impacts on forests and people associated with trade and investment in emerging economies?

- to mitigate the negative and enhance the positive social, economic and environmental impacts of trade and investment linked to food and biofuel markets, and promote more responsible investments?

- to support improved governance, especially for securing the land and resource rights of local people, and promote more equitable distribution of benefits in the context of large-scale land-based investment?

- to shift from illegal to legal forest practices that ensure sustainable forest management while securing the livelihoods of local forest users and other stakeholders?

- to reduce the risks of corruption and fraud associated with forest crime, and forest-related money laundering in public funds and payments (including REDD+ transfers)?

What combinations of factors and governance instruments produce positive gains for sustainability and equity goals?
What measures can be designed to safeguard the livelihoods of vulnerable groups (including women) under threat from trade and investment-driven pressures leading to deforestation and forest degradation?

How can policy frameworks link the need for sustainable forestbased resource management with greater gender equity?

What measures are needed to protect the rights of the most vulnerable groups from largescale land acquisition? What is the role of women in shaping the social and local responses to commercial pressures on land linked to trade and investment? What kinds of arrangements (including information and resources) are required to link such local responses to national and transnational networks focused on making international trade and investment more accountable to local actors?
Identification of improved principles, sustainability standards and safeguards to promote responsible trade and investment and more effective institutional systems for enhancing legality linked to forest management and trade, and combat fraud and corruption associated with forest

Identified improved policy frameworks and institutional options for regulating and managing the impacts on forests and people associated with trade and investment, strengthening forest and land governance systems, integrated law enforcement approaches, and equitable benefit sharing

Enhancement of instruments and platforms for policy analysis and dialogue in producer countries on best policies, regulatory frameworks and improved practices for managing social, economic and environmental impacts linked to trade and investment

Synthesis of comparative analysis with recommendations on policy options 

This research was carried out by CIFOR as part of the CGIAR Research Program on Forests, Trees and Agroforestry. This collaborative program aims to enhance the management and use of forests, agroforestry Forests, Trees and and tree genetic resources across the landscape from forests to farms. CIFOR leads the program in partnership Agroforestry with Bioversity International, CIRAD (Centre de coopérationinter nationale en recherche agronomique pour le développement), the International Center for Tropical Agriculture and the World Agroforestry Centre. 